\title{
The Miocene Red Lake macroflora of the Deadman River Formation (Chilcotin Group), Interior Plateau, British Columbia, Canada
}

\author{
DAVID R. GREENWOOD ${ }^{1 *}$, CHRISTOPHER K. WEST ${ }^{2}$ and JAMES F. BASINGER ${ }^{2}$ \\ ${ }^{1}$ Department of Biology, Brandon University, 270-18 ${ }^{\text {th }}$ Street, Brandon, Manitoba, R7A 6A9, Canada; \\ e-mail: greenwoodD@brandonu.ca \\ ${ }^{2}$ Department of Geological Sciences, University of Saskatchewan, 114 Science Place, Saskatoon, \\ Saskatchewan, S7N 5E2, Canada; e-mail: christopher.west@usask.ca (CKW), jim.basinger@usask.ca (JB)
}

Received 19 June 2020; accepted for publication 12 October 2020

\begin{abstract}
Despite early interest in Neogene floras, primarily Miocene sites associated with Mio-Pliocene volcanic deposits of the Interior Plateau of British Columbia, few systematic accounts of the Miocene macrofloras of British Columbia - or elsewhere in non-Arctic Canada - have been published since the pioneering studies of J.W. Dawson and his contemporaries in the late $19^{\text {th }}$ century. In this report, the Red Lake macroflora from sediments of the middle Miocene Deadman River Formation exposed in the Red Lake diatomite mine north of Kamloops, British Columbia, is illustrated, and a preliminary assessment presented, along with a brief review of Miocene floras from British Columbia and the U.S. Pacific Northwest. The Red Lake macroflora contains rare Ginkgo leaves, shoots of Cupressaceae (Cupressinocladus, Metasequoia, Taxodium) and shoots and seeds of Pinaceae (Pseudotsuga, Tsuga), maple (Acer) seeds and leaves, Liquidambar (fruit), Trochodendraceae (Zizyphoides auriculata leaves, Nordenskioeldia interglacialis fruits), leaves of 4 species of red and white oaks (Quercus columbiana, Q. prelobata, Q. pseudolyrata, Quercus sp.), leaves of an alder (Alnus harneyana) and birch (Betula thor), chestnut (Castanea spokanensis), beech (Fagus pacifica), sycamore (Platanus dissecta), elm (Ulmus speciosa), leaves of unidentified taxa, fruits of Tilia pedunculata (Malvaceae) and fruits and inflorescences of other unidentified taxa, and leaves of a reed or rush (indet. monocot). The Red Lake middle Miocene climate reconstructed from leaf physiognomy was temperate and mesic, with mean annual temperature $\sim 11-13^{\circ} \mathrm{C}$, mild winters (coldest month mean temperature $\sim 3^{\circ} \mathrm{C}$ ), mean annual precipitation $170-51 /+73 \mathrm{~cm} / \mathrm{yr}$, and growing season precipitation $\sim 92 \mathrm{~cm}$, with moderate seasonality of precipitation (three wettest months $\sim 51 \mathrm{~cm}$ vs. three driest months $\sim 25 \mathrm{~cm}$ ). The Red Lake flora shows similarities to middle to late Miocene floras from the U.S. Pacific Northwest (i.e., richness in oaks) but is of much lower diversity and lacks key elements common to many of the contemporaneous U.S. Miocene floras (e.g., foliage of Pinaceae esp. Pinus), and is missing taxa detected in the microflora, a pattern likely due to sampling effectiveness at the Red Lake Mine and sampling of different lithofacies for macro- and microfloras.
\end{abstract}

KEYWORDS: Red Lake, Miocene, macroflora, British Columbia, Canada, palaeoclimate

\section{INTRODUCTION}

The Miocene was a time of modernization of the North American flora, having plant communities of nearly modern floristic character by the middle and late Miocene, as reconstructed from macrofloras and microfloras (e.g., Wolfe, 1966; Robichaux and Taylor, 1977; Wolfe and

\footnotetext{
Corresponding author
}

Tanai, 1980; Axelrod et al., 1991; Graham, 1993; Wing, 1998; Graham, 1999; Williams et al., 2008; Pound et al., 2011; Dillhoff et al., 2014; Baskin and Baskin, 2016; Prader et al., 2017, 2020), as well as phytoliths (e.g., Harris et al., 2017). The climate of Miocene western North America reconstructed from fossil plants was cooler than for earlier Epochs, with 
increasing seasonal dryness near the end of the Miocene, in part as a result of continued uplift in the Pacific Northwest of the Cascade Range and Coast Mountains of British Columbia, which contributed to the development of the modern rain shadow in the region (Graham, 1993, 1999; Reiners et al., 2002; Potter and Szatmari, 2009; Yang et al., 2011; Harris et al., 2017). Knowledge of Canadian Miocene vegetation and climates is largely limited to microfloras from British Columbia (e.g., Mathews and Rouse, 1963, 1984; Martin and Rouse, 1966; Hopkins, 1968; Clague, 1974; Rouse and Mathews, 1979), or to early to middle Miocene floras from the Arctic (e.g., Hills and Ogilvie, 1970; Hills et al., 1974; Hickey et al., 1988; Matthews and Ovenden, 1990; Whitlock and Dawson, 1990; White et al., 1997; Williams et al., 2008; Fig. 1). A number of fossil macrofloras reported as Miocene from British Columbia by early workers such as J.W. Dawson (1883), G.M. Dawson (1895) and Penhallow (1908) have subsequently been shown to be Eocene (Mathews and Rouse, 1963; Greenwood et al., 2016; Eberle and Greenwood, 2017). Beyond the Arctic, sparse accounts and mostly anecdotal data are provided for Miocene macrofloras from western Canada (e.g., Hollick, 1927; Berry, 1929; Mathews and Rouse, 1963, 1984; Martin and Rouse, 1966; Clague, 1974; Rouse and Mathews, 1979; Axelrod et al., 1991; Manchester et al., 1991). Canadian Miocene macrofloras are consequently often missing or underrepresented from regional, North American and global summaries of Miocene vegetation and climate (e.g., Axelrod et al., 1991; Wing, 1998; Graham, 1999; Pound et al., 2011; Yang et al., 2011; Henrot et al., 2017). In their review of Platanus dissecta Lesq., Huegele et al. (2020) reported this fossil leaf widely from Miocene macrofloras across the Pacific Northwest, but they did not list any Canadian localities for $P$. dissecta.

Middle to late Miocene macrofloras are well described from the Pacific Northwestern states of Idaho (ID), Oregon (OR) and Washington (WA) of the United States (Fig. 1; e.g., Berry, 1931, 1934; Smith, 1941; Chaney and Axelrod, 1959; Graham, 1963, 1993; Smiley et al., 1975; Cross and Taggart, 1982; Pigg et al., 2004; Buechler et al., 2007; Dillhoff et al., 2014; Mustoe and Leopold, 2014; Pinson et al., 2018; Smith and Manchester, 2019). Petrified wood of the Ginkgo Petrified Forest
State Park and Yakima Canyon, (Wheeler and Dillhoff, 2009) and permineralized plants from Yakima Canyon (Pigg et al., 2004) add to our knowledge of the Pacific Northwest Miocene flora. These Pacific Northwest macrofloras are interpreted as mixed conifer-deciduous broadleaf forests containing exotic elements such as Metasequoia and Trochodendraceae, as well as typical extant eastern and southeastern forest genera such as Carya, Castanea, Fagus, Liquidambar, Sassafras and Taxodium, together with more cosmopolitan tree and shrub genera such as Abies, Acer, Alnus, Amelanchier, Betula, Picea, Pinus, Platanus, Populus, Quercus, Salix, Thuja, Tsuga, Ulmus and Vaccinium (Tab. 1). Quercus underwent considerable diversification during the Miocene, with North American Miocene macrofloras providing a rich record of oak leaves (Barrón et al., 2017).

Robichaux and Taylor (1977) listed nine Miocene macrofloras from the U.S. Pacific Northwest and noted similarities between these floras and the modern vegetation of the mixed conifer forest of middle elevations in the Sierra Nevada of California. Some taxa present in the Pacific Northwest macrofloras appear to herald the modern western regional flora (e.g., Pseudotsuga and Mahonia). Taxa extinct in present-day North America and now restricted to Eastern Asia were still present in these Miocene floras, a feature typical of the older, warmer Eocene floras of British Columbia and much of the continental U.S. such as Ginkgo, Glyptostrobus, Metasequoia, Pterocarya (Juglandaceae) and Trochodendraceae (Robichaux and Taylor, 1977; Axelrod et al., 1991; Manchester et al., 1991, 2018; Baskin and Baskin, 2016). Miocene floras from Alaska and the Yukon reveal middle to late Miocene vegetation comparable to that reconstructed from macrofloras for Idaho, Oregon and Washington, with a floristically rich mixed conifer-deciduous broadleaf forest that included Taxodium or Metasequoia (and other Cupressaceae), Acer, Fagaceae, Ilex, Juglandaceae, Liquidambar, Nyssa, Tilia, Tsuga, Trochodendraceae and Ulmus (Wolfe and Tanai, 1980; Axelrod et al., 1991; Manchester et al., 1991; White et al., 1997). Knowledge of what grew during the middle to late Miocene between Oregon and Alaska-Yukon - that is, in British Columbia - is limited (see Fig. 1), however, and is reviewed below. 


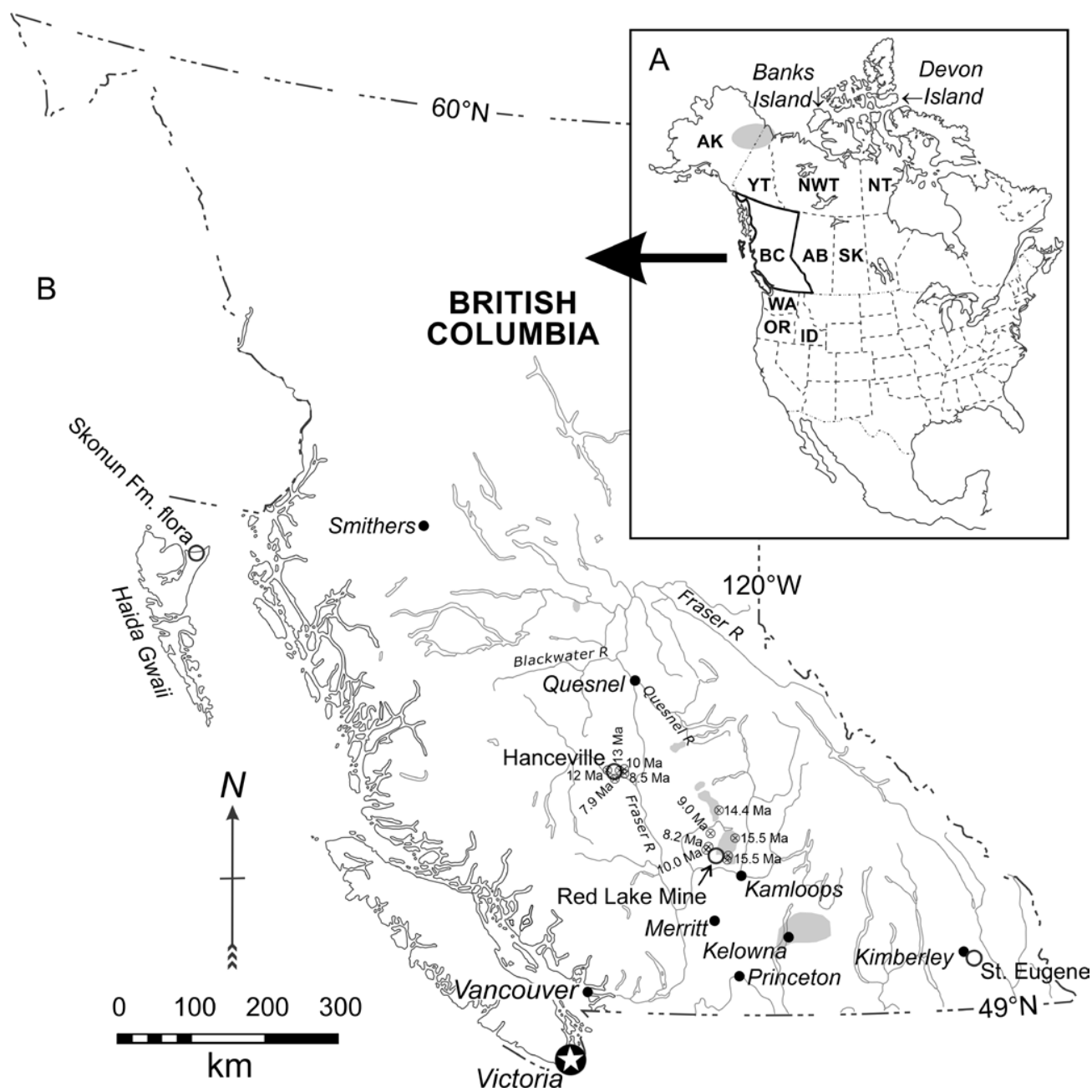

Fig. 1. Map of British Columbia, showing the location of the Red Lake Mine and the principal fossil localities from Canada mentioned in the text (O). (A). Inset map of North America, showing the principal areas where other Miocene floras have been reported in Canada and the Pacific Northwest. The area where Miocene to Pliocene microfloras were described from Alaska and Yukon by White et al. (1997) is shown as a shaded ellipse. (B). Detail map of British Columbia, showing the location of Miocene leaf floras in British Columbia mentioned in the text $(O$ and the location $(\otimes)$ of K-Ar dates proximal to the Red Lake Mine from Mathews (1989), with the value in millions of years (Ma). Shaded areas are Middle Miocene Chilcotin Group basalts (Mathews, 1989). Selected cities and towns are shown $(\bullet / \bullet)$ for orientation. Base map modified from Eberle and Greenwood et al. (2017). AB, Alberta; AK, Alaska; BC, British Columbia; ID, Idaho; NT, Nunavut; NWT, Northwest Territories; OR, Oregon; SK, Saskatchewan; WA, Washington

\section{MIOCENE FLORAS OF BRITISH COLUMBIA}

In early accounts of the "Tertiary floras" of the Interior of British Columbia (BC), many macrofloras were initially thought to be Miocene (J.W. Dawson, 1883; G.M. Dawson, 1895; Penhallow, 1908); however, most of these floras are now recognized as Eocene (Mathews and Rouse, 1963; Greenwood et al., 2016; Eberle and Greenwood, 2017) and are not discussed further here, except for J.W. Dawson (1883) and Penhallow's (1908) account of floras from the Quesnel and Blackwater rivers (Fig. 1), as these may represent Miocene strata. Penhallow (1908) lists Blackwater River under the Eocene as part of the "Lignite Tertiary", but also as one of the "Miocene localities", and states that Quesnel "must be regarded as Eocene" (Penhallow, 1908: p. 111). Dawson's earlier accounts were summarized by Penhallow (1908: p. 28), who listed the following taxa (leaves, unless qualified) from Quesnel: Taxodium?, Acer, Betula, Carya (nut), Castanea castaneafolia, Dombeyopsis islandica Heer, Fagus (2 spp.), Juglans (nut and a leaf), Nordenskioeldia borealis Heer (NB: a late Cretaceous to Eocene species; Wang et al., 2009), Nyssydium? (sic), Platanus aceroides Goeppert, Populus arctica Heer, 2 spp. of Quercus (incl. Q. pseudocastanea Goeppert), and Rhamnus sp.; and from the Blackwater River: Acer, Castanea castaneafolia (Unger) Knowlton, Diospyros alaskana Schimper, Fagus, Pinus 
Table 1. A comparison of Miocene leaf macrofloras from northwestern North America mentioned in the text, arranged in order of their geological age. From Dawson (1883); Penhallow (1908); Hollick (1927); Smith (1941); Chaney (1959); Chaney and Axelrod (1959); Graham (1963); Mathews and Rouse (1963); Axelrod (1964); Clague (1974); Smiley et al. (1975); Rouse and Mathews (1979); Champigny et al. (1981); Wolfe and Tanai (1987); Mathews (1989) (age); Manchester et al. (1991); Bolton (1994); Baghai and Jorstad (1995); Graham (1993); Graham (1999); Buechler et al. (2007); Dillhoff et al. (2014); Manchester and Rember (2014); and, Smith and Manchester (2019); and this study (Red Lake). BC, British Columbia; ID, Idaho; OR, Oregon; WA, Washington

\begin{tabular}{|c|c|c|c|c|c|c|c|c|c|c|c|c|c|c|c|c|c|}
\hline Flora & 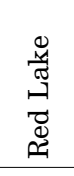 & 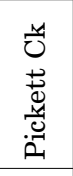 & 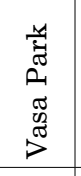 & 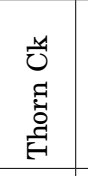 & 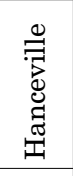 & $\begin{array}{l}\vec{\Phi} \\
\tilde{g} \\
\tilde{0} \\
\vec{\sigma}\end{array}$ & 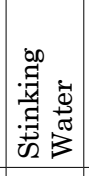 & 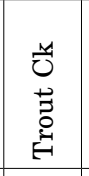 & 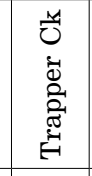 & 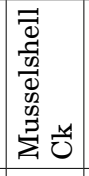 & 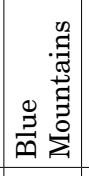 & 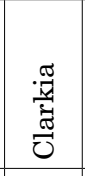 & 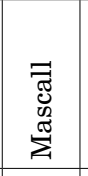 & 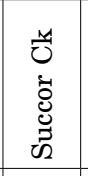 & 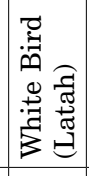 & 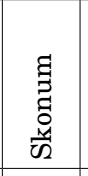 & 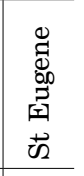 \\
\hline State or province & O & 目 & $\mathbb{3}$ & 目 & Ö & Ö & 它 & 今્ય & $\theta$ & 目 & శ્ય & A & 行 & $\begin{array}{l}\text { A } \\
\text { هi }\end{array}$ & $\widehat{B}$ & O & Ö \\
\hline Age & 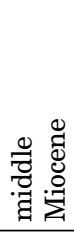 & 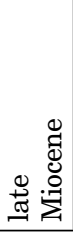 & 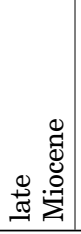 & 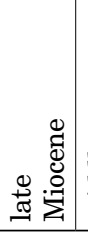 & 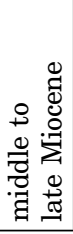 & 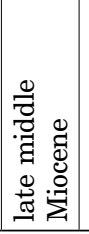 & 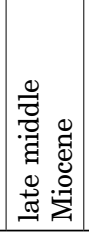 & 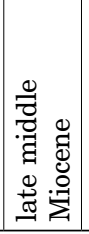 & 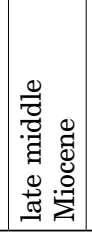 & 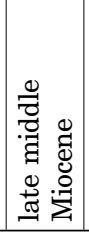 & 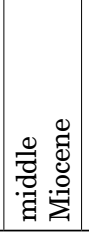 & 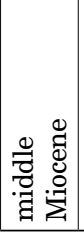 & 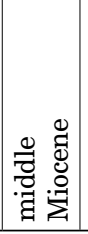 & 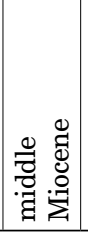 & 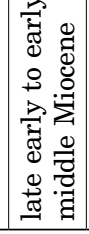 & 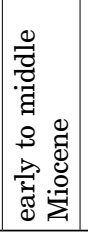 & 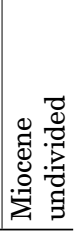 \\
\hline
\end{tabular}

Abies

Chamaecyparis / Thuja

Ginkgo

Glyptostrobus

Metasequoia

Picea

Pinus

Pseudotsuga

Taxodium

Tsuga

Acer

Ailanthus

Alnus

Amelanchier

Betula

Carpinus

Carya

Castanea

Celtis

Cornus

Crataegus

Diospyros

Fagus

Fraxinus

Gordonia

Gymnocladus

Hydrangea

Ilex

Juglans

Liquidambar

Magnolia

Mahonia

Nordenskioeldia

Nyssa

Ostrya

Persea

Platanus

Populus

Prunus

Pterocarya

Quercus

Rhamnus

Rhus

Salix

Sassafras

Tilia

Ulmus 
(as seeds), Taxodium occidentale Newberry (syn. Metasequoia occidentalis (Newberry) Chaney) and Thuja (as "Thuya"). As the Quesnel area includes Eocene, Miocene and younger strata that have yielded macroflora and mammals (Mathews and Rouse, 1963, 1984; Rouse and Mathews, 1979; Eberle and Greenwood, 2017), it is not possible to say with confidence that these taxa represent Miocene macrofloras of the British Columbia Interior Plateau.

An additional Miocene macroflora was reported from the St. Eugene silts (St. Eugene Formation of Clague, 1974) in the Kootenay region of southeastern British Columbia (Fig. 1) by Hollick (1927) and Berry (1929). Clague (1974) subsequently provided data on the St. Eugene Formation microflora, updated Hollick's (1927) list, and noted leaf taxa such as Alnus, Betula ulmoides Hollick, Carya egregia (Lesq.) LaMotte, Hicoria pseudovata Hollick, Cocculus heteromorpha (Knowlton) Brown (syn. Zizyphoides auriculata (Heer) Manchester et al., 1991), Fagus, Platanus dissecta Lesq., Quercus kootenayensis Hollick, Tilia and other taxa. The taxa reported from the St. Eugene silts flora by Clague (1974) and earlier workers are in need of revision, as, for example Hickoria pseudovata is a synonym of Carya benderei (Lesq.) Chaney et Axelrod (1959), and the type of $C$. egregia was considered by Chaney and Axelrod (1959: p. 156) to be Gordonia. In their analysis of Miocene Trochodendraceae fruits and leaves, Manchester et al. (1991) listed the holotype of fruits of Nordenskioeldia interglacialis (Hollick) Manchester et al. from the St. Eugene Miocene flora, a record also noted by Wang et al. (2009). The St. Eugene flora otherwise seems to have been subsequently overlooked, as it does not appear in summaries of regional Miocene macrofloras (e.g., Wing, 1998; Pound et al., 2011; Dillhoff et al., 2014), and the record of Platanus dissecta from the St. Eugene silts was not included in Huegele et al. (2020). Hollick's fossil leaf collection is in the Geological Survey of Canada palaeontological collection (Bell, 1962), which is now curated in the Canadian Museum of Nature in Ottawa. Plant fossil localities that are part of the GSC palaeontological collection are listed herein as "GSC pl. loc.".

Rouse and his co-workers described Miocene leaf floras from Haida Gwaii (i.e., Queen Charlotte Islands, Fig. 1; Martin and Rouse, 1966) and also from the British Columbia
Interior (Mathews and Rouse, 1963, 1984; Rouse and Mathews, 1979; see also Wolfe and Tanai, 1987). While focused on the microflora from the early to middle Miocene Skonun Formation (Champigny et al., 1981), Martin and Rouse (1966: p. 171) noted a small collection of leaves "well preserved in a calcareous siltstone" that included Alnus and Pterocarya, but offered no further comment. Wolfe and Tanai (1987) reported leaves of Acer brownii from "Skonun" on the Queen Charlotte Islands (i.e., Haida Gwai, Fig. 1).

Mathews and Rouse (1963) reported a series of floras from a "late Tertiary succession" of volcanic rocks from northwest of Kamloops BC which contained fossiliferous sediments (Fig. 1), including the Red Lake flora (Chilcotin Group, Deadman River Formation). In that and in later reports, Mathews and Rouse (Mathews and Rouse, 1963, 1984; Rouse and Mathews, 1979) reported principally on the microfloras of the "Late Tertiary plateau basalts" from the BC Interior Plateau - including the Fraser Bend Formation and overlying Crownite Formation - and for the lower Middle Miocene Fraser Bend Formation noted separate Quercus-Fagus and Tsuga-Cedrus palynofacies vs. a Picea-Cedrus facies for the Crownite Formation, inferring a shift to cooler conditions by the time of deposition of the Middle Miocene Crownite Formation.

Wolfe and Tanai (1987) reported samaras and leaves of Acer from a site they listed as "early Miocene, Chilcotin River" (GSC pl. loc. 5786) but that Bolton (1994) lists as "Miocene, Hanceville, BC" (Fig. 1). Mathews and Rouse (Mathews and Rouse, 1963; Rouse and Mathews, 1979) correlated sediments at Hanceville with the early Middle Miocene Fraser Bend Formation. Mathews and Rouse (1963) reported a K-Ar date of $12 \mathrm{Ma}$ for basalt on top of the Hanceville plant fossil beds, with Mathews (1989) reporting K-Ar ages of $13-7.9 \pm 0.6 \mathrm{Ma}$ in the immediate area (Fig. 1), placing this flora as late middle to late Miocene.

Mathews and Rouse (1963) anecdotally noted the following macrofloral taxa as found in sedimentary rocks under or included within the "late Tertiary lavas" (Chilcotin Gp. of later workers; Mathews, 1989; Read, 2000): the fern Osmunda macrophylla Penhallow; the conifers Taxodium dubium (Sternberg) Heer, Sequoia affinis Lesq. and Metasequoia 
occidentalis; and the broadleaf angiosperms Alnus harneyana Chaney et Axelrod, Betula thor Knowlton, Quercus (Q. simulata Knowlton, $Q$. dayana Knowlton and $Q$. eoprinus Smith), Ulmus speciosa Newberry, Mahonia reticulata (MacGinitie) Brown, Platanus dissecta and a species of Acer (see also Wolfe and Tanai, 1987). Unfortunately, Mathews and Rouse (1963) did not specify which macrofloral taxa were found at the specific localities, including Red Lake, and provided no illustrations of the macroflora. However, Rouse and Mathews (1979: p. 437) did note common leaf elements (viz. Alnus harneyana, A. hollandia Jennings, Quercus hannibali Dorf, Q. simulata, Q. dayana and Ulmus speciosa) between the middle to late Miocene Stinking Water and Trout Creek floras of Oregon and that of the diatomite Crownite Formation near Quesnel, and inferred a late middle Miocene age for its fossil flora.

Here we provide a preliminary account of leaves and fruits which several researchers collected between the 1980s and 2000s from the Red Lake Miocene locality; they are housed in the Thompson Rivers University Institute of Palaeontological Research collection (TRUIPR; collector(s) unknown) and the University of Saskatchewan palaeobotanical collection (USPC; collected by J.F. Basinger). The USPC Red Lake collection is being transferred to the Royal British Columbia Museum. Based on this account, we offer further insights into the character of middle Miocene vegetation and the climates of British Columbia. We also provide (1) a preliminary climate reconstruction using leaf physiognomy (cf. Yang et al., 2011); (2) a comparison between the taxa of the Red Lake flora and those of the "late Tertiary lava" floras of the BC Interior, previously presented anecdotally by earlier workers; and (3) a comparison between the Red Lake Mine flora and that of contemporaneous macrofloras from Idaho, Oregon and Washington (i.e., the U.S. Pacific Northwest).

\section{GEOLOGICAL SETTING}

The Red Lake Mine is located $\sim 46 \mathrm{~km}$ northwest of Kamloops, British Columbia, Canada (Fig. $1 ; 50^{\circ} 56^{\prime} 28^{\prime \prime} \mathrm{N}, 120^{\circ} 48^{\prime} 50^{\prime \prime} \mathrm{W}$ ) at $1315 \mathrm{~m}$ elevation, and supplies diatomaceous earth (Read, 1989, 1992, 1996; Simandl et al., 2001; Aylen et al., 2004; Gurney, 2016). Read (1992, 1996) described the mine lithostratigraphy within the context of regional geology, and his account is paraphrased here, with rock unit nomenclature from Simandl et al. (2001) and Aylen et al. (2004) (Fig. 2). Rock units exposed in the Red Lake Mine are members of the Mio-Pliocene Chilcotin Group (Bevier, 1983; Mathews, 1989), which includes the Deadman River and Chasm formations (Read, 2000). Within the mine workings a grey andesite of the Eocene Kamloops Group was exposed; it was overlain by the Deadman River Formation. The Deadman River Formation consists of fluvio-lacustrine sediments with up to $7 \mathrm{~m}$ of diatomaceous
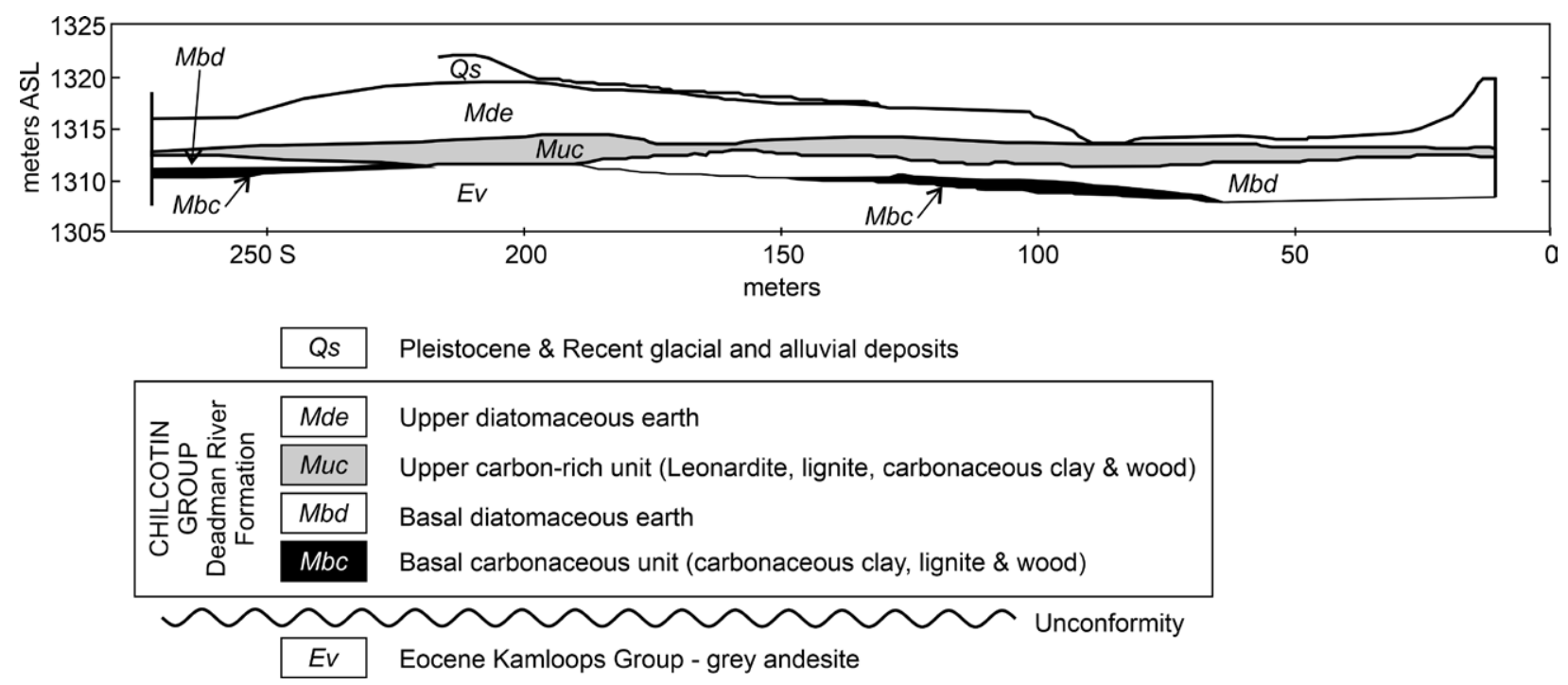

Fig. 2. Geology of the Red Lake Mine site, showing the stratigraphic relationships of the units of the Miocene Deadman River Formation, which is the source of the microflora reported by Mathews and Rouse (1963) and the macroflora reported here. Adapted from the N-S transect at $150 \mathrm{~m}$ E of Read (1996) from Simandl et al. (2001) 
earth found in two stratigraphically separate units: lower (Mbd, $\sim 2 \mathrm{~m}$ ) and upper (Mde, $\sim 5 \mathrm{~m}$; Fig. 2). The basal and upper diatomaceous earth units are interleaved with upper (Muc) and lower (Mbc) carbonaceous units containing minor lignitic coal, wood including tree trunks, and carbonaceous claystones (Read, 1992, 1996; Aylen et al., 2004; Gurney, 2016) that are the likely source(s) of the microflora reported by Mathews and Rouse (1963). The leaf flora reported here is of unknown origin within the mine stratigraphy (as the fossils were collected from a mine spoil heap) but the macroflora is from either unit Mbd or unit Mde (Fig. 2). Unit Mbd (the basal diatomaceous earth) is described as "rich in plant debris" (Gurney, 2016); however, unit Mde is the likely source of any spoil heap, as this is the unit that is actively mined and is described by Aylen et al. (2004) as beige to pale grey or brownish in colour, matching the fossil matrix.

The difference between the paleolatitude and the modern latitude of the Red Lake flora is not relevant to consideration of the flora, as the continental configuration by the middle Miocene was nearly identical to the modern position (Potter and Szatmari, 2009). However, there were some key paleogeographic and paleotopographic differences in North America at this time. Orogenic processes that began in the middle Miocene, including renewed uplift of the Rocky Mountains, as well as continued uplift of the Cascade Range of the Pacific Northwest and Coast Mountains of BC (Potter and Szatmari, 2009), contributed to the development of the rain shadow and the drierclimate-adapted flora present on the leeward side of these ranges today (Graham, 1999; Retallack et al., 2002; Takechui et al., 2007; Mustoe and Leopold, 2014).

The uplift of the Coast Mountains occurred concomitantly with eruption of the Chilcotin Group basalts in British Columbia (Bevier, 1983; Mathews, 1989) - a Neogene volcanic event that produced approximately $2.5 \times$ $10^{3} \mathrm{~km}^{3}$ of lava in central and southern British Columbia, principally during the Miocene (Bevier, 1983; Mathews, 1989; Dostal et al., 1996). Similar to the geomorphic events in British Columbia, the uplift of the Cascade Range occurred contemporaneously with the eruption of the nearby Columbia River Basalt Group in Washington, Oregon and Idaho (Kasbohm and Schoene, 2018), a volcanic event that produced upwards of $2.1 \times 10^{5} \mathrm{~km}^{3}$ of lava in the Pacific Northwest between $\sim 17 \mathrm{Ma}$ and $5 \mathrm{Ma}$ (Kasbohm and Schoene, 2018). Thus, the current geomorphic interpretation suggests that the Interior Plateau, and the Red Lake flora, would have been near or at its present-day elevation by the middle to late Miocene (Reiners et al., 2002; Potter and Szatmari, 2009).

Mathews and Rouse (1963) provided a K-Ar date of $10 \pm 2 \mathrm{Ma}$ for volcanic rocks from strata correlated to those they sampled for their analysis of the Red Lake Mine microflora. Bevier (1983) dated the Chilcotin Group basalts from K-Ar analyses mostly in the range 10-6 Ma. Additional K-Ar dates from Chilcotin Group basalts clustered near the Red Lake Mine (Fig. 1) range from $15.5 \pm 0.5 \mathrm{Ma}$ to $8.2 \pm 0.3 \mathrm{Ma}$, with the Red Lake Mine within an area mapped as Middle Miocene basalts with a cluster of K-Ar dates of $15.5 \pm 0.5 \mathrm{Ma}$ (Mathews, 1989). Whole-rock K-Ar dates are imprecise, but the K-Ar dates for correlated proximal Chilcotin Group basalts (Fig. 1) place the Red Lake flora as likely middle Miocene (i.e., K-Ar 15.5 $\pm 0.5 \mathrm{Ma}$ ) and not Pliocene as reported by Mathews and Rouse (1963).

\section{MATERIALS AND METHODS}

Only a small set of fossils was available for our study ( 81 specimens; Tab. 2): $\sim 64$ specimens at the University of Saskatchewan collected in 1991 from a spoil heap, and a smaller collection of 17 specimens from the Thompson Rivers University Institute of Palaeontological Research, Kamloops, British Columbia (TRUIPR; Red Lake Mine is locality L-053). Specimens were photographed using a Nikon DS3200 DSLR camera with a $60 \mathrm{~mm}$ macro lens. Specimens collected by J.F. Basinger are temporarily in the Brandon University paleobotany collection, on loan from the University of Saskatchewan Paleobotanical Collection (USPC; Red Lake Mine is locality USPC 72), but will be permanently transferred to the Royal British Columbia Museum, so these specimens are listed with their RBCM accession numbers (e.g., RBCM P1539).

All leaf specimens were assigned to morphotypes defined as part of this study using the protocol in the Manual of Leaf Architecture (Ellis et al., 2009). In some cases, additional leaf traits not included in the Manual of Leaf Architecture were included in the descriptions (e.g., vein angle measurements), as these traits were considered diagnostic for the leaf. Samaras of Acer were described using the terminology of Wolfe and Tanai (1987). Where possible, fossil leaves and reproductive structures were identified based on published accounts of Miocene floras from the Pacific Northwest of North America (e.g., Berry, 1934; Smith, 
Table 2. List of taxa from the Red Lake flora. Only "dicot" leaf taxa used in leaf physiognomic analysis of palaeoclimate (CLAMP, LMA and LAA) were given a morphotype number. F-numbers from TRUIP and P-numbers from RBCM

\begin{tabular}{|c|c|c|c|}
\hline $\begin{array}{l}\text { Morphotype } \\
\text { number }\end{array}$ & Referred specimens & $\begin{array}{l}\text { Organ } \\
\text { type }\end{array}$ & Identity \\
\hline- & F-009 & leaf & Ginkgo cf. G. adiantoides (Unger) Heer \\
\hline- & F-004 & shoot & Pseudotsuga cf. P. sonomensis Dorf \\
\hline- & P1488 & seed & Tsuga cf. T. sonomensis Dorf \\
\hline- & P1489 & shoot & Cupressinocladus sp. indet. \\
\hline- & P1490, P1491 & shoot & Taxodium cf. T. dubium (Sternberg) Heer \\
\hline- & P1492, F-005 & shoot & Metasequoia occidentalis (Newberry) Chaney \\
\hline 008 & P1493, P1538, P1539 & leaf & Platanus dissecta Lesq. \\
\hline 006 & P1494, P1495, P1496, P1497, F-013 & leaf & Zyziphoides auriculata (Heer) Manchester et al. \\
\hline- & P1498 & fruit & Nordenskioeldia interglacialis (Hollick) Manchester et al. \\
\hline- & F-0011a\&b & fruit & Liquidambar sp. indet. \\
\hline 014 & P1499, F-010c & leaf & Ulmus speciosa Newberry \\
\hline 016 & $\mathrm{P} 1500, \mathrm{P} 1502, \mathrm{P} 1503$ & leaf & Quercus columbiana Chaney \\
\hline 017 & P1504, P1505, F-014, & leaf & Quercus prelobata Condit \\
\hline 019 & P1501, P1506, P1507, P1521, F-010a & leaf & Quercus pseudolyrata Lesq. \\
\hline 020 & $\begin{array}{l}\text { P1509, P1510, P1511, P1522, F-001, } \\
\text { F-002, F-011, F-015, F-017 }\end{array}$ & leaf & Quercus sp. indet. \\
\hline 009 & $\mathrm{P} 1512, \mathrm{P} 1513$ & leaf & Castanea spokanensis (Knowlton) Chaney et Axelrod \\
\hline 012 & $\mathrm{P} 1514$ & leaf & Fagus pacifica Chaney \\
\hline- & $\mathrm{P} 1515$ & fruit & Genus et species indet. \\
\hline 007 & $\mathrm{P} 1516$ & leaf & Alnus harneyana Chaney et Axelrod \\
\hline 005 & P1517, F001 & leaf & Betula thor Knowlton \\
\hline- & $\mathrm{P} 1532$ & fruit & Betula sp. indet. \\
\hline & F-016, P1518 & fruit & Tilia pedunculata Chaney \\
\hline- & $\mathrm{P} 1519$ & fruit & Acer aff. A. brownii Wolfe et Tanai \\
\hline 011 & $\mathrm{P} 1520$ & leaf & Acer sp. indet. \\
\hline 001 & $\mathrm{P} 1521$ & leaf & Dicotylophyllum sp. 1 \\
\hline 018 & F003 & leaf & Dicotylophyllum sp. 2 \\
\hline 002 & $\mathrm{P} 1523$ & leaf & Dicotylophyllum sp. 3 \\
\hline 003 & $\mathrm{P} 1524, \mathrm{P} 1525$ & leaf & Dicotylophyllum sp. 4 \\
\hline 004 & $\mathrm{P} 1526$ & leaf & Dicotylophyllum sp. 5 \\
\hline 015 & P1527 & leaf & Dicotylophyllum sp. 6 \\
\hline 013 & P1528 & leaf & Dicotylophyllum sp. 7 \\
\hline- & P1529 & leaf & Dictoylophyllum sp. 8 \\
\hline 020 & P1530 & leaf & Dicotylophyllum sp. 9 \\
\hline- & P1532 & fruit & Genus et species indet. \\
\hline- & P1533 & fruits? & Genus et species indet. \\
\hline- & P1534 & fruit & Genus et species indet. \\
\hline- & $\mathrm{P} 1535$ & fruit & Genus et species indet. \\
\hline- & P1536, P1537 & leaf & Monocotylophyllum sp. \\
\hline
\end{tabular}

1941; Chaney and Axelrod, 1959; Graham, 1963; Wolfe and Tanai, 1980, 1987; Manchester et al., 1991, 2018; Manchester, 1994; Buechler et al., 2007; Dillhoff et al., 2014; Huegele et al., 2020).

Additionally, leaves were scored for leaf physiognomic analysis to reconstruct palaeoclimate , applying univariate leaf margin analysis (LMA) and leaf area analysis (LAA), as well as the multivariate CLAMP method (Wilf et al., 1998; Greenwood, 2007 and references therein; Peppe et al., 2011; Yang et al., 2011, 2015). For CLAMP, analysis was completed online by uploading the CLAMP scoresheet, and using the Physg3brcAZ/GRIDMet3brAZ calibration (Yang et al., 2011;
Yang et al., 2015). The CLAMP score sheet and LMA and LAA data sheets are provided in the supplementary files ${ }^{1}$. All fossils were measured using the digital measurement tool in IC Measure ver. 1.2.0.233 (The Imaging Source, 2015), which was calibrated using the scale in the fossil specimen images. For the gymnosperms we used the linear classification of Christenhusz et al. (2011), and for the families of angiosperms the classification from APG IV (2016).

1 Supplementary File 1: Leaf margin analysis and leaf area analysis data file; Supplementary File 2: CLAMP score sheet 


\section{SYSTEMATICS}

Gymnosperms

Order: Ginkgoales Gorozh., 1904

Family: Ginkgoaceae Engl., 1897

Genus: Ginkgo L., 1771

\section{cf. Ginkgo adiantoides (Unger) Heer}

Pl. 1, fig. 1

Description. Small incomplete flabellate leaf ( 2.5 length $\times \sim 3.3 \mathrm{~cm}$ width) with dichotomously branched veins, and irregularly crenate margin on distal end of blade.

Material ex a mined. TRUIPR L-053 F-009.

Remarks. A single partial Ginkgo leaf was part of the TRUIPR collection (Pl. 1, fig. 1). This leaf shows the diagnostic dichotomously branching veins on a flabellate lamina typical of extant $G$. biloba L. and the fossil taxon $G$. adiantoides. The leaf is poorly preserved and some veins are either missing or very faint or laterally displaced due to decay of the mesophyll tissue, giving the false impression of irregularly spaced veins. Ginkgo biloba leaves may range from bilobed, with the main two lobes partially dissected, to unlobed on the same branch, and considerably smaller than typical if leaf-flush occurs during a dry period (DG, pers. obs.). Lott et al. (2019) described a specimen from the Alum Bluff Miocene flora of Florida of similar size as L-053 F-009, and referred their specimen to the fern cf. Adiantum on the basis that the lower blade was lobed and the margin was inrolled on the distal edge of the blade. However, the Red Lake specimen lacks any of these features, and all available morphology, including the size of the lamina, are consistent with Ginkgo. Chaney and Axelrod (1959) speculated that Ginkgo was becoming extinct in western North America by the late Miocene. Ginkgo adiantioides or G. biloba are recorded in several other western North American middle Miocene floras (Tab. 1). Petrified wood of Ginkgo beckii Scott et al. is known from Ginkgo Petrified Forest State Park in Vantage, Washington, and is regarded as among the youngest occurrences $(\sim 15.5 \mathrm{Ma})$ of Ginkgo in western North America (Scott et al., 1962; Wheeler and Dillhoff, 2009), but
Buechler et al. (2007) did not record Ginkgo in the late Miocene Pickett Creek (Oregon) flora.

Order: Pinales Lindley, 1836

Family: Pinaceae Lindley, 1836

Genus: Pseudotsuga Carrière, 1867

\section{Pseudotsuga sonomensis Dorf (shoot)}

Pl. 1, fig. 2

Description. Leafy shoot bearing slender linear to lanceolate leaves $4.5-5.5 \mathrm{~cm}$ long $(n=4)$ and $0.5-0.6 \mathrm{~cm}$ wide $(n=7)$, with prominent midvein central groove, leaves at $32-57^{\circ}$ angle to branch $(n=6)$. Leaf apices narrowing to blunt point; base narrowing at point of attachment to branch and flexed upward on petiole-like short stalk.

Material examined. TRUIPR L-053 F-004.

Remarks. Extant species of Tsuga (e.g., T. canadensis (L.) Carr., T. heterophylla (Raf.) Sarg., T. mertensiana (Bong.) Carr.) generally have short needles $(\sim 1-2 \times 0.2-0.3 \mathrm{~cm})$ with quite rounded apices, whereas extant species of Pseudotsuga (e.g., P. macrocarpa (Vasey) Mayr, P. menziesii (Mirbel) Franco and $P$. sinensis Dode) have long needles ( $\sim 2-8$ $\times 0.1-0.2 \mathrm{~cm}$ ) relative to Tsuga, with both genera having essentially linear needles on short petiole-like stalks, as seen on L-053 F-004 (Pl. 1, fig. 2). This leafy shoot specimen from the TRUIPR collection is similar to Pseudotsuga sonomensis from the Blue Mountains flora (Chaney and Axelrod, 1959: Pl. 13, fig. 13). The extant species Pseudotsuga menziesii and $P$. wilsoniana, and the Miocene $P$. sonomensis, each have a centre-line groove on the upper needle surface, and two prominent stomatal bands either side of the midvein on the lower needle surface are visible on $P$. menziesii and $P$. wilsoniana. Red Lake specimen L-053 F-004 shows a prominent leaf-midvein central groove on linear leaves attached to the branch by short petiole-like stalks. This character is consistent with identification as Pseudotsuga, but the specimen lacks any leaves showing stomatal bands. Chaney and Axelrod (1959) did not report $P$. sonomensis needle sizes, and their illustrations lack a scale. The somewhat morphologically similar Tsuga sonomensis Axelrod (cf. Chaney and Axelrod, 1959: Pl. 13, figs 9, 10) 

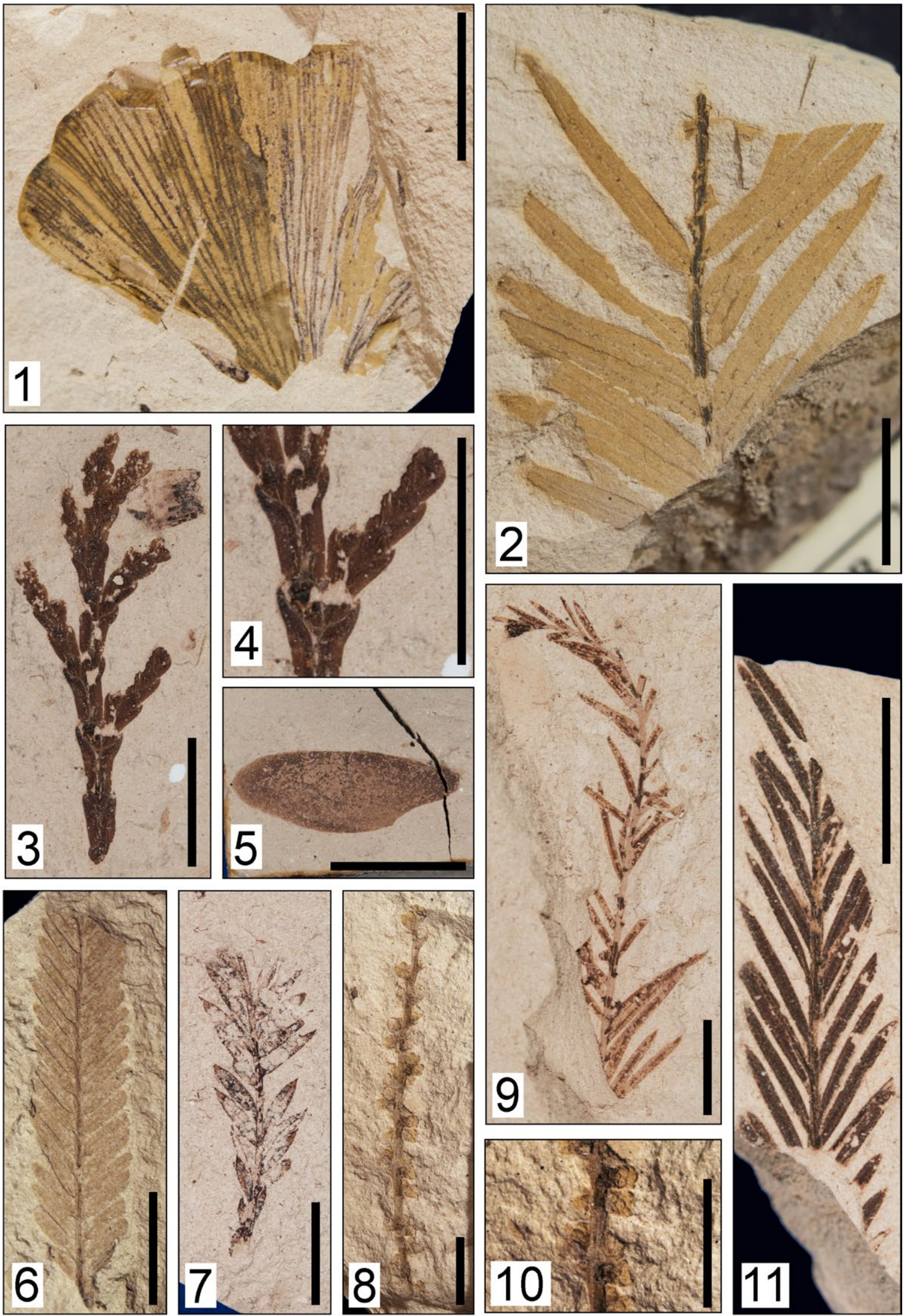

Plate 1. 1. Ginkgo cf. G. adiantoides (Unger) Heer, leaf specimen, TRUIPR L-053 F-009; 2. Pseudotsuga sonomensis Dorf, leafy shoot specimen, TRUIPR L-053 F-004; 3, 4. Cupressinocladus sp., 3. branch with branchlets, RBCM P1489; 4. enlarged image of RBCM P1489, showing hooked scales; 5. Tsuga cf. T. sonomensis Dorf, seed, RBCM P1488; 6. Metasequoia occidentalis (Newberry) Chaney, shoot, showing closely spaced leaves, TRUIPR L-053 F-005; 7. Sequoia sp., shoot, showing broad ellipticshaped leaves, RBCM P1492; 8, 10. Gymnosperm gen. et sp. indet. unidentified staminate cone axis, TRUIPR L-053 F-007; 8. whole specimen; 10. enlarged to show the clustered pollen cones; 9, 11. Taxodium cf. T. dubium; 9. Leafy shoot, showing more narrow lanceolate leaves, RBCM P1490; 11. Leafy shoot, showing broader leaves, RBCM P1491. Scale bars $=1 \mathrm{~cm}$ 
also has slender linear needles, but, at $0.4-$ $2.0 \mathrm{~cm}$ long with blunt rounded apices, it is typical of extant Tsuga, and its leaves are much smaller than the Red Lake specimen's leaves, which are comparable in size to $P$. sonomensis and to which we refer the Red Lake specimen. Pseudotsuga sonomensis is known from leafy shoots and cones and is recorded from the Blue Mountains, Trout Creek (both OR), and Thorn Creek (ID) Miocene floras (Chaney and Axelrod, 1959) (Tab. 1).

Genus: Tsuga (Endl.) Carrière, 1855

\section{cf. Tsuga sonomensis Dorf (seed)}

Pl. 1, fig. 5

Description. Seed, $\sim 17 \mathrm{~mm}$ long, $\sim 6 \mathrm{~mm}$ wide at widest part of wing; $2.5 \mathrm{~mm}$ wide at narrowest point; roughly falcate to deltoid in outline; widest near midpoint of seed, tapers to rounded acute tip.

\section{Material examined. RBCM P1488}

Remarks. Described from a single specimen that includes part and counterpart, this fossil is similar to other material referred to as Tsuga sonomensis; however, the limited material available for study and its preservation quality limit a firm taxonomic assignment at this time.

Order: Cupressales Link, 1829

Family: Cupressaceae Gray, 1822

$$
\begin{gathered}
\text { Fossil-genus: Cupressinocladus } \\
\text { Seward, } 1919 \text { (shoot) }
\end{gathered}
$$

\section{Cupressinocladus sp.}

$$
\text { Pl. 1, figs 3, } 4
$$

Description. Branch incomplete, branching alternate, forming flat spray $\sim 35 \mathrm{~mm}$ long; branchlets arising from junctions of lateral leaves, up to $9.3 \mathrm{~mm}$ long, up to $6.8 \mathrm{~mm}$ apart along main axis, branchlets at $\sim 27-36^{\circ}$ angle $(n=4)$ to main axis. Leaves scale-like, appearing decussate. Facial leaves on branches and branchlets poorly preserved and not observed on specimen examined. Lateral leaves of branch $\sim 5.5 \mathrm{~mm}$ long, $1.1 \mathrm{~mm}$ wide, appearing falcate with acute to rounded apices. Lateral leaves of branchlets up to $3 \mathrm{~mm}$ long, $<1 \mathrm{~mm}$ wide, also falcate with acute apices; bases poorly preserved or obscured by preceding lateral leaves.

\section{Material examined. RBCM P1489.}

Remarks. This specimen (Pl. 1, fig. 4) shows the appressed leaves typical of Chamaecyparis and Thuja (Cupressaceae), with RL32 a good match for Thuja dimorpha (Oliver) Chaney et Axelrod from the Miocene Blue Mountains flora (cf. Chaney and Axelrod, 1959: Pl. 14, fig. 1). However, due to the absence of fertile material and the difficulty of distinguishing foliage of Chamaecyparis from Thuja, this specimen is placed in Cupressinocladus (sensu Zijlstra and Kvaček, 2010).

Genus: Taxodium Rich., 1810

\section{cf. Taxodium dubium (Sternberg) Heer}

Pl. 1, figs 9, 11

Description. Incomplete leafy shoots bearing alternate lanceolate leaves; leaves $5-13 \times$ $0.9 \mathrm{~mm}(n=10)$; apices appear acute, rarely rounded; leaf base decurrent, petiolate, attached obliquely to axis; leaves at $24-35^{\circ}$ angle to branch $(n=10)$.

Material examined. RBCM P1490, P1491.

R e marks. These shoot specimens (Pl. 1, figs 9, 10) show the spreading-leaf pseudo-distichous pattern seen in Glyptostrobus, Sequoia and Taxodium. Morphologically the specimens from Red Lake are a good match for Taxodium dubium, a taxon found at several Miocene localities from the Pacific Northwest (Tab. 1), including Mascall (Oregon) and the Latah Formation (Washington, Idaho), where it is dominant, according to Chaney and Axelrod (1959). Glyptostrobus oregonensis Brown is also reported from several Pacific Northwest Miocene floras, based on seed cones and attached foliage. Sterile foliage of $G$. oregonensis illustrated by Chaney and Axelrod (1959: Pl. 15, fig. 6) also resembles the Red Lake specimens, illustrating the difficulty of identifying similar sterile foliage; T. dubium is a better match, however. No seed or staminate cones were found in the Red Lake material. In the absence of characters on these specimens that would allow assignment of conifer shoots showing this morphology to an extant genus, Kvaček (2015) recommended that such specimens could be referred to the fossil genus 
Elatocladus Halle, but also suggested that an affinity to extant genera may also be appropriate, an approach we have chosen to follow in this case, where the close similarity to Taxodium dubium permits assignment of the fossil to Taxodium.

Genus: Metasequoia Hu et W.C. Cheng, 1948

\section{Metasequoia occidentalis}

(Newberry) Chaney

$$
\text { Pl. 1, fig. } 6
$$

Description. Leafy branchlet $\sim 3.5 \mathrm{~cm}$ long $(n=1)$. Leaves opposite and decussate, rarely sub-opposite, closely clustered, midvein distinct. Leaf shape ovate to linear, $0.5-0.6 \times 0.1-$ $0.15 \mathrm{~cm}(n=18)$; leaf apex rounded or acute, base symmetrical, petiole short, attachment decurrent, attachment twisted on facial leaves.

Material examined. TRUIPR L-053 F-005.

Re m arks. Specimen L-053 F-005 (Pl. 1, fig. 6) is consistent with Metasequoia occidentalis but we note the absence of seed cones in the Red Lake macroflora. Metasequoia is not commonly reported from Miocene floras across the Pacific Northwest, principally occurring at Hanceville and Quesnel (BC), Musselshell Creek (Idaho) and Mascall (Oregon) (Tab. 1).

Genus: Sequoia Endl., 1847

\section{Sequoia sp.}

Pl. 1, fig. 7

Description. Leafy branchlet $\sim 3 \mathrm{~cm}$ long $(n=1)$. Leaves alternate, petiolate; leaf shape lanceolate, 4-8 $\mathrm{mm}$ long, $1-1.5 \mathrm{~mm}$ wide $(n=14)$; leaf apex acuminate, base acute, petiole short, attachment excurrent, attachment appears twisted; proximal leaves appear small or scale-like.

\section{Material examined. RBCM P1492.}

Remarks. The size, shape and arrangement of the leaves on this leafy branchlet indicate that this fossil is Sequoia.

Gymnosperms gen. et sp. indet.

$$
\text { Pl. 1, fig. 8, } 10
$$

Description. Pollen cones, alternate or whorled, and terminal; globular or ovate in shape, 2-3 mm long, 1-2 mm wide, borne singly or in clusters of 2 or 3 , up to $1.4-3.7 \mathrm{~mm}$ apart along axis $\sim 55 \mathrm{~mm}$ long; cones sessile or peduncular.

Material exam in ed. TRUIPR L-053 F-007 and F-008 (part and counterpart).

R e m arks. Described from a single specimen that includes part and counterpart, this fossil appears to be coniferous pollen cones that broadly appear to belong to Cupressaceae, but the state of preservation and limited material prevent assignment.

\section{Angiosperms}

Eudicots

Order: Proteales Juss. ex Bercht. et J.Presl, 1820

Family: Platanaceae T. Lestib., 1826

Genus: Platanus L., 1753

\section{Platanus dissecta}

Lesq. emend. Huegele et al.

Pl. 2, figs 1-3

Description. Leaf attachment petiolate, laminar size notophyll to mesophyll $(\sim 8.5-15$ $\times \sim 8.5-11.2 \mathrm{~cm} ; n=3$ ), laminar shape ovate to elliptic, palmately trilobed, margin serrate. Apex not preserved; base angle reflexed, base shape cordate. Primary venation palinactinodromous; angle between primary lobe midvein and lateral lobe midveins $26-45^{\circ}(n=6)$; simple agrophic veins present; secondary venation craspedodromous; secondary vein spacing irregular; secondary vein angle uniform; secondary vein attachment to midvein deflected; intersecondary veins present; tertiary vein fabric percurrent, opposite; tertiary vein course straight to convex. Teeth widely spaced, 2 orders of teeth present, teeth prominent and spinose, sinuses rounded, tooth shape concave-convex.

Material examined. RBCM P1493, P1538, P1539.

Rem arks. Platanus dissecta has been widely reported from Miocene floras across western North America (Chaney and Axelrod, 1959; Huegele et al., 2020). Graham (1963) erected a new species, Platanus youngii Graham, for a single leaf specimen from Succor Creek 

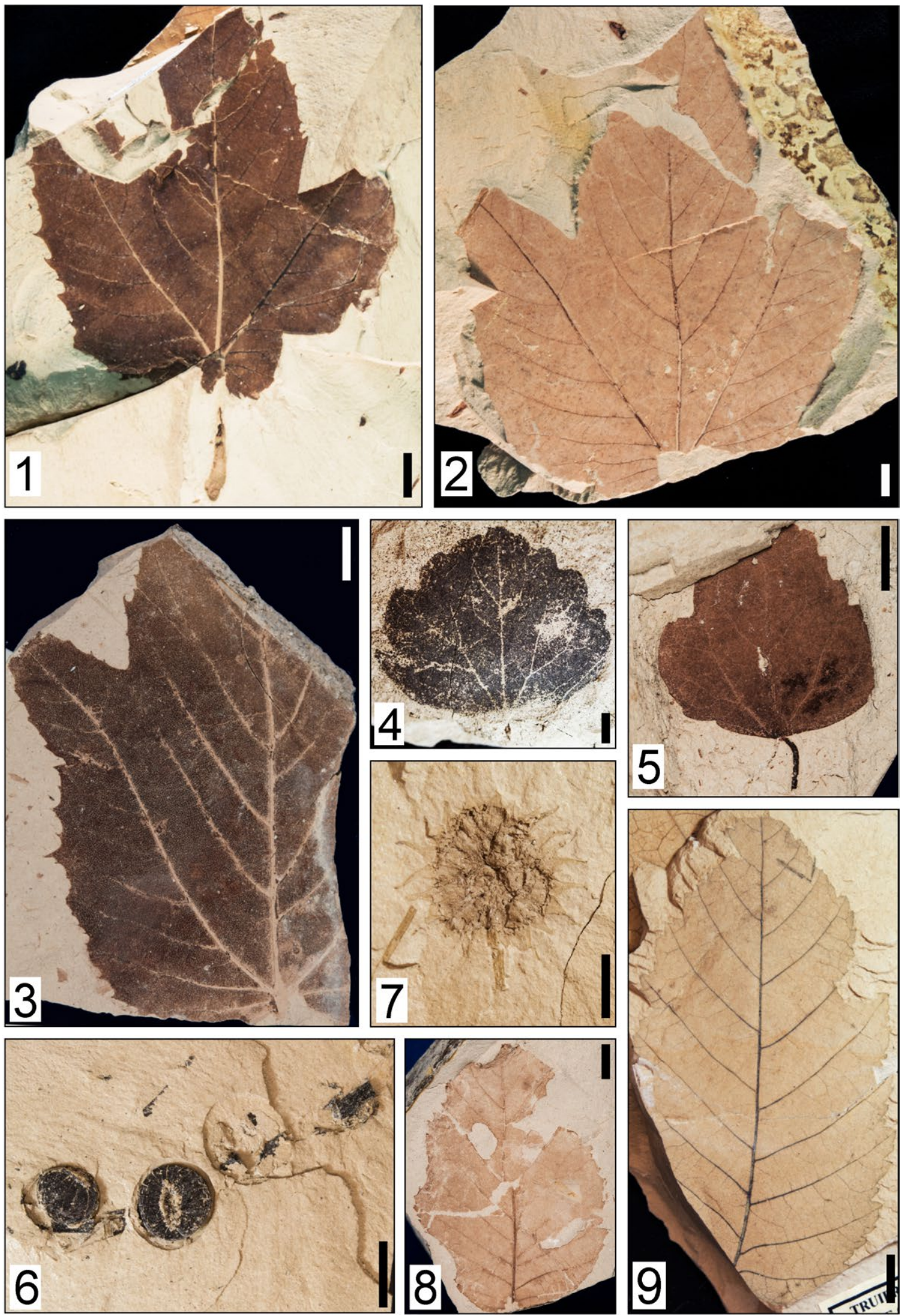

Plate 2. 1-3. Platanus dissecta Lesquereux emend. Huegele et al., 1. leaf with preserved petiole and robust marginal teeth, RBCM P1538, 2. leaf, showing secondary venation along primary vein, RBCM P1493, 3. leaf, showing smaller lobes and marginal teeth variation, RBCM P1539; 4, 5. Zizyphoides auriculata (Heer) Manchester et al., 4. leaf, showing an ovate shape and broad round teeth, TRUIPR L-053 F-013, 5. leaf, showing a more elliptic shape and preserved petiole, RBCM P1496; 6. Nordenskioeldia interglacialis (Hollick) Manchester et al., fruit-bearing stalk, TRUIPR L-053 F-018; 7. Liquidambar cf. L. changii Pigg et al., woody infructesence, TRUIPR L-053 F-011; 8, 9. Ulmus speciosa Newberry, 8. leaf, showing a preserved base and margin with small serrate teeth, RBCM P1499, 9. leaf, showing robust doubly serrate margin, TRUIPR L-053 F-010. Scale bars $=1 \mathrm{~cm}$ 
(Oregon) previously assigned to $P$. dissecta, and the leaves P1493, P1538 and P1539 from Red Lake (Pl. 2, figs 1-3) resemble the material illustrated by Graham (1963: fig. 12); specimen P1493 shows the same leaf architecture, but the prominent teeth are poorly preserved. The Red Lake material differs from $P$. youngii principally in the greater depth of the sinus between the lower pair of lobes and the central lobe. Wolfe and Tanai (1980) referred some Platanus leaves attributed to $P$. dissecta and $P$. youngii to $P$. bendirei (Lesq.) Wolfe, but Huegele et al. (2020), in a review of nomenclature and type and other referred specimens of $P$. dissecta and other Miocene Acer and Platanus species of morphology comparable to $P$. dissecta (e.g., $P$. bendirei and $P$. youngii), synonymized these species within their expanded concept of $P$. dissecta. We apply their morphological concept to the fossils we assign here to P. dissecta.

Chaney and Axelrod (1959) recorded P. dissecta from Mascall, the Blue Mountains, Stinking Water, and Succor Creek in Oregon, White Bird in Idaho (Latah Formation) and other Miocene localities in the Pacific Northwest (Tab. 1). The type of $P$. dissecta is from Table Mountain (California), with additional records from California, Seldovia Point in Alaska, Clarkia in Oregon, and localities in Washington listed by Huegele et al. (2020). Mathews and Rouse (1963) reported $P$. dissecta from the "late Tertiary lavas" (Chilcotin Gp. of later workers; Mathews, 1989; Read, 2000) of south central British Columbia, a record missing from the compilation of Huegele et al. (2020: Tab. 2).

Order: Trochodendrales

Takht. ex Cronquist, 1981

Family: Trochodendraceae Eichler, 1865

Fossil-genus: Zizyphoides Newberry, 1863

\section{Zizyphoides auriculata}

(Heer) Manchester et al.

$$
\text { Pl. 2, figs 4, } 5
$$

Description. Leaf petiolate, laminar size microphyll $(3.5-6.5 \times 3.4-9 \mathrm{~cm} ; n=4)$, laminar shape ovate to ovate-elliptical, margin crenately serrate. Apex angle obtuse, apex shape straight; base angle obtuse, base shape rounded. Primary venation basal actinodromous, with veins that branch on their lower side; agrophic veins not present; secondary venation semicraspedodromous; secondary vein spacing increases proximally; secondary vein angle uniform; secondary vein attachment to midvein excurrent; tertiary venation percurrent; tertiary vein fabric opposite and weakly convex; tertiary vein angle perpendicular to obtuse. Tooth spacing regular, one order of teeth, sinus shape rounded; tooth shape convex-convex to straight-convex.

Material examined. TRUIPR L-053 F-013; RBCM P1494, P1495, P1496, P1497.

Remarks. These small leaves from the Red Lake flora (Pl. 2, figs 4, 5) correspond well to Zizyphoides auriculata (see figs 18, 19 in Manchester et al., 1991). Manchester et al. (1991) included within their circumscription of Z. auriculata the taxa Populus heteromorpha Knowlton, Populus fairii Knowlton, Cocculus heteromorpha (Knowlton) Brown, Cebatha multiformis Hollick, Cebatha heteromorpha (Knowlton) Berry and probably also Cissampelos dubiosa Hollick. Zizyphoides auriculata is therefore recorded for a range of Miocene floras (Tab. 1), including the St. Eugene silts flora of BC (Fig. 1), Grand Coulee and Spokane from Washington, and White Bird, Clarkia, and Musselshell Creek in Idaho (Manchester et al., 1991; Baghai and Jorstad, 1995).

Fossil-genus: Nordenskioeldia Heer, 1870

Nordenskioeldia interglacialis (Hollick) Manchester et al.

$$
\text { Pl. 2, fig. } 6
$$

Description. Short infructescence $\sim 6 \mathrm{~cm}$ in length, bearing four circular schizocarpous sessile fruits $\sim 1 \mathrm{~cm}$ across, attached singly, of which two fruits were missing from the specimen. One of the remaining fruits is divided into $\sim 22$ radial segments or mericarps ("fruitlets"), whereas the second remaining fruit is preserved in lateral view and only shows $\sim 8-10$ fruitlets.

Material examined. TRUIPR L-053 F-018.

Remarks. A single specimen from the TRUIPR collection of fruits on a stalk (Pl. 2, fig. 6) shows the characteristic morphology of Nordenskioeldia and is assigned to $N$. interglacialis, 
a Miocene species first described by Hollick (1927) as Ficus interglacialis Hollick from the St. Eugene silts (St. Eugene Formation of Clague 1974; GSC pl. loc. 4958) in the Kootenay region of southeastern BC (Fig. 1). Manchester et al. (1991) and Wang et al. (2009) reported for $N$. interglacialis elliptical to circular sessile fruits $9-12 \mathrm{~mm}$ across in transverse view, with 14-29 fruitlets (typically 18-24), consistent with the Red Lake specimen. Manchester et al. (1991) reported $N$. interglacialis from several Miocene floras from Washington and Idaho. Nordenskioeldia borealis Heer - a late Cretaceous to Eocene species known from North America, Spitzbergen, Russia and China - is reported in Canada from the Northwest Territories, Axel Heiberg and Ellesmere islands in Nunavut, and Quesnel River, BC (Penhallow, 1908; Crane et al., 1991; McIver and Basinger, 1999; Wang et al., 2009; West et al., 2019). As the fruits Nordenskioeldia interglacialis at Red Lake are found in association with the Trochodendraceae leaf taxon Zizyphoides auriculata, they are likely from the same plant species.

\section{Superrosids}

Order: Saxifragales Bercht. et J.Presl, 1820

Family: Altingiaceae Horan., 1841

Genus: Liquidambar L., 1753

\section{cf. Liquidambar changii Pigg et al.}

Pl. 2, fig. 7

Description. A globose pistillate woody infructesence $\sim 20 \mathrm{~mm}$ in diameter, borne on a woody peduncle, with $\sim 21$ fruits visible with elongate curved styles with broad stigmatic surfaces.

Material examined. TRUIPR L-053 F-011a, b.

Re m arks. A single infructesence in the TRUIPR collection (Pl. 2, fig. 7) shows the diagnostic characters of Liquidambar (Pigg et al., 2004; Ickert-Bond et al., 2005). The styles are curved and not coiled, as seen in the extant species Liquidambar acalycina H.T. Chang, L. orientalis L. and L. styraciflua L. The fossil has 21 fruits, comparable to Liquidambar acalycina (17-26 fruits, vs 32-48 for the other extant species; Ickert-Bond et al., 2005), but fewer fruits than reported for the middle Miocene anatomically preserved $L$. changii from Yakima Canyon in Washington ( 25-30; Pigg et al., 2004). The width of the TRUIPR infructesence specimen is at the lower end of the range of the four extant Liquidambar species ( $20 \mathrm{~mm}$ vs. mean width $17-32 \mathrm{~mm}$ ) and comparable to L. acalycina $(18-31 \mathrm{~mm}$; Ickert-Bond et al., 2005). The Red Lake Liquidambar infructesence is slightly smaller than but otherwise comparable to $L$. changii (width $\sim 25 \mathrm{~mm}$ ) from Yakima Canyon (Pigg et al., 2004). Differences in the style of preservation of $L$. changii and the TRUIPR Red Lake fossil make detailed comparisons difficult, as key characters observed on the threedimensionally preserved $L$. changii cannot be observed on the Red Lake specimen; however, superficially these two fossils appear similar and may be conspecific. Pigg et al. (2004) proposed a close relationship between the middle Miocene $L$. changii and the extant $L$. acalycina of central and south China. Liquidambar is reported from Middle Miocene sites in Idaho, Oregon and Washington (Tab. 1).

\section{Rosids / Fabids}

Order: Rosales Bercht. et J.Presl, 1820

Family: Ulmaceae Mirb., 1815

Genus: Ulmus L., 1753

\section{Ulmus speciosa Newberry}

Pl. 2, figs 8,9

De s c rip tio n. Leaf attachment not preserved, laminar size microphyll to notophyll ( 7.8-10 $\times \sim 5.2-5.5 \mathrm{~cm} ; n=2$ ), laminar shape ovate to oblong, margin serrate. Apex not preserved; base not preserved, base weakly asymmetrical. Primary venation pinnate; agrophic veins absent; secondary venation craspedodromous, with 10-12 secondary veins, each extending into largest teeth; secondary vein spacing uniform; secondary vein angle smoothly decreasing proximally; secondary vein attachment to midvein excurrent and proximally decurrent; secondary veins slightly curving upward over outermost 1/3 of their course, except for lowermost pair which are almost at a right angle to midvein; intersecondary veins absent; tertiary vein fabric percurrent and alternate. Tooth 
spacing regular, 2 orders of teeth, sinus shape rounded, tooth shape convex-convex to flexuous-convex.

Material examined. RBCM P1499; TRUIPR L-053 F-010c

Remarks. Ulmus speciosa is a taxon common to several Miocene floras from Idaho and Oregon but which spans a range of leaf morphologies that includes taxa other than Ulmus (Chaney and Axelrod, 1959). However, as circumscribed by Chaney and Axelrod (1959: p. 174, Pl. 32, figs 1-5) U. speciosa is a good match for leaf P1499 from the Red Lake flora collections (Pl. 2, figs $8,9)$. Specimen P1499 has a poorly preserved margin and shows insect leaf-feeding damage. Tanai and Wolfe (1977) circumscribed Ulmus speciosa as being generally ovate to oblong in outline and less asymmetrical and less rounded at the base than some other forms of Ulmus recorded from the Miocene (e.g., Ulmus pseudoamericana Lesq.). Tanai and Wolfe (1977), as part of their taxonomic key to different species of Ulmus, described U. speciosa as being doubly serrate along the margin; however, both doubly serrate and singly serrate forms have been figured to represent Ulmus speciosa (e.g., Tanai and Wolfe, 1977: p. 26, Pl. 26, figs C, F). Specimen P1499, although poorly preserved, does contain margin remnants that show doubly serrate teeth, as well as other characteristics (ovate shape, reduced basal asymmetry) that align closely with $U$. speciosa. Mathews and Rouse (1963) reported, without illustration, Ulmus speciosa from the diatomite Crownite Formation near Quesnel (BC), and Ulmus species are known from many Miocene floras from the Pacific Northwest (Tab. 1).

Order: Fagales Engl., 1892

Family: Fagaceae Dumort., 1829

\section{Genus: Quercus L., 1753}

The most common leaves in the Red Lake collections are oaks (Quercus spp.). Fossil oak leaves and pollen are relatively common from Oligocene and younger floras from North America, including the Miocene floras of the Pacific Northwest (Tab. 1). The North American Quercus fossil record documents diversification of Quercus into a range of habitats during the Neogene (Barrón et al., 2017), but there is considerable confusion as to the nomenclature and synonymy of fossil oak leaves (Chaney and Axelrod, 1959; Buechler et al., 2007; Barrón et al., 2017). Barrón et al. (2017) discussed at length the problems with assigning leaf fossils to species of Quercus (fossil or extant), noting the difficulty in identifying living oaks from leaves, which results from the marked morphological variation within species (often on a single tree), and frequent hybridization, likely leading to exaggerated species diversity in the Quercus fossil leaf record. We therefore follow the practice in Barrón et al. (2017) and provisionally accept the published names for fossil oaks and avoid erecting new species, pending a much-needed comprehensive review and stabilization of Quercus fossil leaf taxonomy.

Based on the fossil taxon names provided in the cited works, however, none of the oak leaf taxa present in the Red Lake flora correspond to the species listed for the "late Tertiary lavas" by Mathews and Rouse (1963) or for the underlying Crownite Formation by Rouse and Mathews (1979). Nevertheless, we refer several morphotypes of fossil oak leaves from the Red Lake Mine macroflora to fossil species recognized from other Miocene Pacific Northwest localities. According to sources cited in Barrón et al. (2017: p. 45; see esp. Buechler et al., 2007: p. 331), Q. hannibali and $Q$. dayana are considered to be synonyms of Q. pollardiana (Knowlton) Axelrod, although Chaney and Axelrod (1959) and Buechler et al. (2007) recognized $Q$. hannibali as a valid species that included some material assigned to $Q$. dayana - both taxa named as part of the Crownite Formation macroflora by Rouse and Mathews (1979). Quercus hannibali as figured by Chaney and Axelrod (1959: Pl. 25, figs 11-13) and Buechler et al. (2007: fig. 8H) is quite distinctive, with well developed, widely spaced acute to spinose teeth (although both sets of authors recognized entire-margined examples within their concepts of the species) on an orbicular unlobed lamina, a morphology that has no match with any leaves from Red Lake. Quercus simulata was also listed by Rouse and Mathews (1979); however, this species has a complex synonymy, with different authors illustrating quite contrasting morphologies (Chaney and Axelrod, 1959). As Barrón et al. (2017) note, there is doubt as to whether $Q$. simulata is an oak or another 
genus in the Fagaceae. All of these taxa and also $Q$. eoprinus Smith lack lobes and possess marginal forward-pointing teeth ( \pm for Q. simulata; see Chaney and Axelrod, 1959: Pl. 30, figs $2,3,5-8$ ), whereas most of the oak leaves in the Red Lake collections are lobed. Although Quercus eoprinus (Chaney and Axelrod, 1959: Pl. 26, figs 5, 7; Smith, 1941: Pl. 8, fig. 2) has been reported from the "late Tertiary lavas" by Mathews and Rouse (1963), the presence of rounded marginal teeth (Smith, 1941: Pl. 8, fig. 2) precludes it from being a good match for any of the Red Lake fossil oak leaves. Quercus spokanensis var. gracilis Berry (1934: Pl. 20, fig. 5) is considered a junior synonym of $Q$. eoprinus by Chaney and Axelrod (1959), and they considered $Q$. spokanensis to be a species of Castanea (C. spokanensis (Knowlton) Chaney et Axelrod (Chaney and Axelrod, 1959). We recognize three named species of Quercus in the Red Lake flora, and recognize a fourth unnamed species that is likely but not definitively recognizable as Quercus.

\section{Quercus columbiana Chaney}

Pl. 3, fig. 1

Description. Leaf attachment petiolate, laminar size notophyll $(\sim 7.2 \times \sim 3.9 \mathrm{~cm} ; n=2)$, laminar shape obovate to elliptic; margin pinnately lobed to serrate. Apex angle acute, apex shape straight; base angle acute, base shape cuneate. Primary venation pinnate; agrophic veins absent; secondary venation craspedodromous with 8-12 secondary veins, each extending into a tooth or lobe; secondary vein spacing uniform; secondary vein angle uniform to gradually increasing proximally; secondary vein attachment to midvein excurrent; intersecondary veins absent; tertiary vein fabric not preserved. Tooth spacing regular, 1 order of teeth, sinus shape rounded, tooth shape convex-convex.

Material examined. RBCM P1500, P1502, P1503.

Remarks. Quercus columbiana has incipient lobes and secondary veins running to the "tooth" apex (Axelrod and Chaney, 1959: Pl. 26, figs 1-4; Buechler et al., 2007: fig. 6C), both features recognized in several Red Lake specimens (Pl. 3, fig. 1). The Red Lake leaves we refer to $Q$. columbiana are a good match for material of this species as illustrated by
Buechler et al. (2007: fig. 6C) from the late Miocene Pickett Creek flora of Idaho, and less so to specimens of $Q$. columbiana illustrated by Chaney and Axelrod (1959: cf. Pl. 26, figs 1-4) from the mid-Miocene Mascall flora of Oregon.

\section{Quercus prelobata Condit}

Pl. 3, figs 2, 3

Description. Leaf attachment not preserved, laminar size microphyll to notophyll $(\sim 5.9-7.0 \times \sim 3.1-3.3 \mathrm{~cm} ; n=2)$, leaf shape not known (leaf incomplete), lobed, margin untoothed. Apex angle acute, apex shape straight; base not preserved. Primary venation pinnate; agrophic veins absent; secondary venation craspedodromous, with $\sim 6-8$ secondary veins, each extending into a lobe; secondary vein spacing gradually increases proximally; secondary vein angle abruptly increases proximally; secondary vein attachment to midvein excurrent; strong intersecondary veins present, which terminate before reaching margin and loop upward into a secondary vein; tertiary venation percurrent; tertiary vein fabric opposite and straight; tertiary vein angle obtuse; exterior tertiary course looped.

Material examined. RBCM P1504, P1505; TRUIPR L-053 F-014.

Remarks. These Red Lake fossil leaves (e.g., Pl. 3, fig. 3) are a good match for Quercus prelobata, a white oak species reported from the late Miocene Pickett Creek Flora of Idaho (Buechler et al., 2007: fig. 8B) and other Miocene floras such as Stinking Water (Chaney and Axelrod, 1959: cf. Pl. 26, figs 8, 9). The rounded-end, simple-outline lobes with deep sinuses of $Q$. prelobata are typical of many extant white oak species. A range of leaf sizes from microphyll to notophyll for $Q$. prelobata were present in the collections, with leaves present in both the TRU smaller collection and the larger collection made by JFB.

\section{Quercus pseudolyrata Lesq.}

Pl. 3, figs 4, 5

Description. Leaf attachment petiolate, laminar size notophyll $(\sim 11.8 \times \sim 5.9 \mathrm{~cm}$; $n=2$ ), laminar shape elliptic, pinnately lobed with apiculate tips, margin untoothed. Apex angle acute, apex shape straight; base angle 

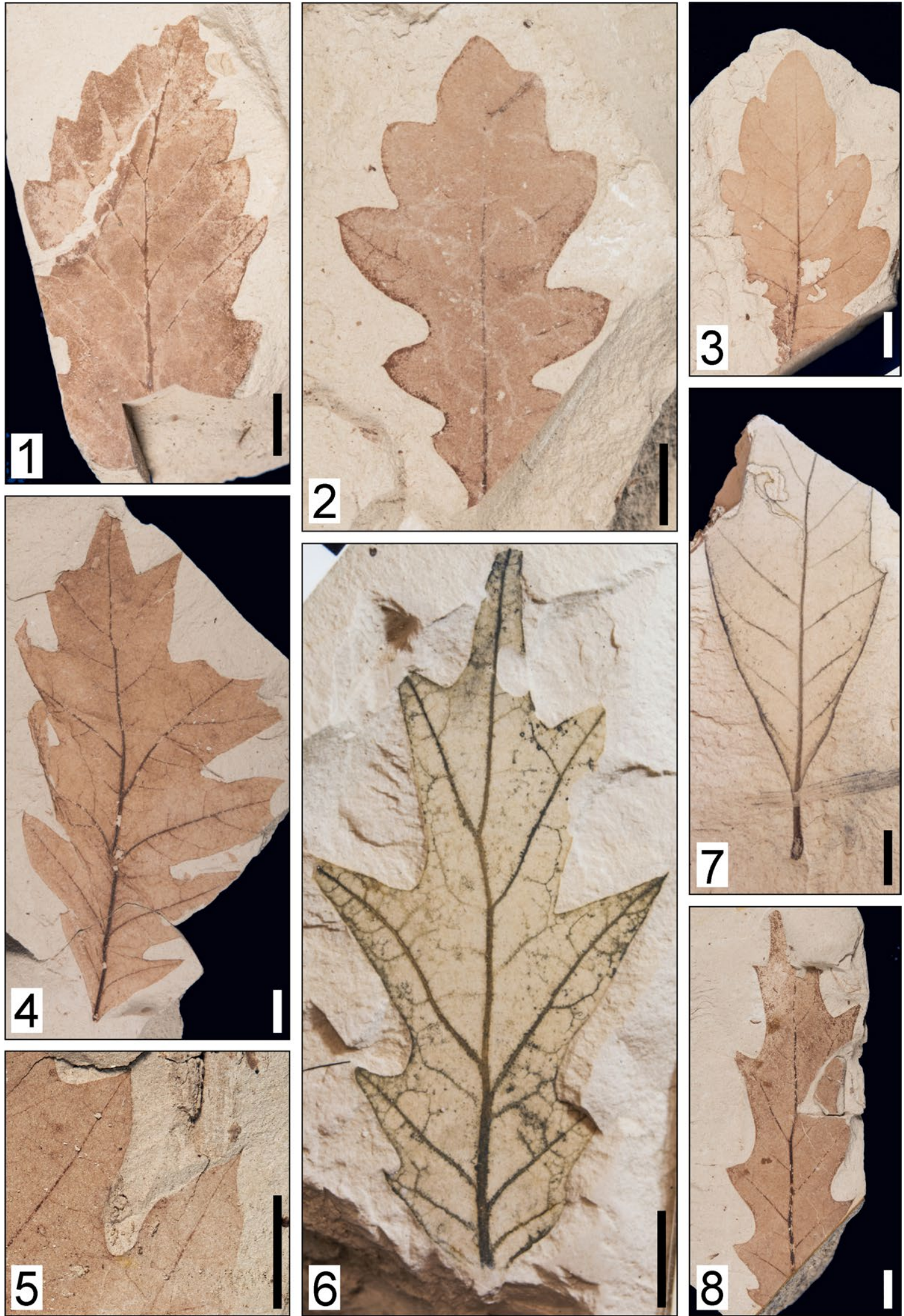

Plate 3. 1. Quercus columbiana Chaney, leaf, showing slightly more upturned lobation verging on marginal serration, RBCM P1503; 2, 3. Quercus prelobata Condit, leaf, showing prominent pinnate lobes, RBCM P1504, 3. Q. prelobata, specimen exemplar, RBCM P1505; 4, 5. Quercus pseudolyrata Lesq., 4. leaf, showing pinnate lobes and apiculate tips, RBCM P1506, 5. enlarged image of lobe with apiculate tips, RBCM P1501; 6-8. Quercus sp., 6. leaf, showing prominent lobes with acute tips, TRUIPR L-053 F-015, 7. leaf, showing acute base with a preserved petiole and small tooth-like projection, TRUIPR L-053 F-017, 8. leaf, showing less pronounced alternate lobes and weak intersecondary veins, RBCM P1509. Scale bars $=1 \mathrm{~cm}$ 
acute, base shape acute. Primary venation pinnate; agrophic veins absent; secondary venation craspedodromous, with 10-14 secondary veins, most extending into a lobe; secondary vein spacing gradually decreases proximally; secondary vein angle irregular; secondary vein attachment to midvein decurrent; weak intersecondary veins present; tertiary vein fabric appears percurrent, alternate.

Material examined. RBCM P1501, P1506, P1507, P1508; TRUIPR L-053 F-010a.

Re marks. These Red Lake specimens (Pl. 3, figs 4, 5) are comparable to Quercus pseudolyrata as illustrated by Smith (1941: Pl. 7, fig. 1), with prominent lobes with deep sinuses and an apiculate lobe tip. In general lobe morphology (i.e., lack of marginal teeth), the specimens from Red Lake appear to be that of a white oak (group Quercus), but the presence of an apiculate or pointed lobe tip is more consistent with being a red oak (group Lobatae), although the extant burr oak (Q. macrocarpa Michx.), one of the white oaks, may have lobes tending towards apiculate. In contrast to the specimens from Red Lake, most specimens of Q. pseudolyrata from Mascall and Stinking Water illustrated by Chaney and Axelrod (1959: cf. Pl. 28, figs $1-4$ and Pl. 29, figs 1,2 ) are clearly red oaks, with sparse marginal teeth along some lobes towards the lobe apices. Other specimens of $Q$. pseudolyrata from Stinking Water show the smooth-margined apiculate lobes of Smith's (1941) material (Chaney and Axelrod, 1959: Pl. 29, figs 3, 4), so we refer the Red Lake specimens to this species.

\section{Quercus sp.}

Pl. 3, figs 6-8

Description. Leaf attachment petiolate, laminar size mesophyll to notophyll ( 7.9-10.3 $\times \sim 2.9-3.7 \mathrm{~cm} ; n=2$ ), laminar shape elliptic to ovate; margin lobed or serrate. Apex angle acute, apex shape straight; base angle acute, base shape straight. Primary venation pinnate; agrophic veins absent; secondary venation craspedodromous, with $\sim 8-11$ secondary veins which extend into a lobe or tooth; secondary vein spacing uniform to gradually decreasing proximally; secondary vein angle uniform; secondary vein attachment to midvein typically excurrent but can be proximally decurrent; weak intersecondary veins may be present; tertiary venation percurrent; tertiary vein fabric alternate; tertiary vein angle obtuse; exterior tertiary course looped. Teeth spacing regular, 1 order of teeth, sinuses rounded, tooth shape convex-convex.

Material examined. TRUIPR L-053 F-001, F-002a, F-015, F-017; RBCM P1509, P1510, P1511, P1522.

Remarks. These Red Lake leaf specimens (Pl. 3, figs 6-8) have lobes that are much shorter and more "deltoid" than is typical of any Miocene Quercus species reported from the Pacific Northwest, or indeed leaves of the modern North American oaks. These leaves appear to be oaks but are outside of the morphology seen typically in extant North American Quercus species. Therefore, while we recognize the genus as Quercus, we refrain from assigning these leaves to a species at this time.

\section{Genus: Castanea Mill., 1754}

\section{Castanea spokanensis}

(Knowlton) Chaney et Axelrod

$$
\text { Pl. 4, figs 1, } 2
$$

Description. Leaf attachment petiolate, laminar size microphyll to notophyll $(\sim 4.3 \times$ $\sim 2 \mathrm{~cm} ; n=1$ ), laminar shape elliptic; margin serrate. Apex angle acute, apex shape straight to acuminate; base angle obtuse, base shape truncate or rounded. Primary venation pinnate; agrophic veins absent; secondary venation craspedodromous; secondary vein spacing irregular; secondary vein angle increases proximally; secondary vein attachment to midvein excurrent; intersecondary veins absent; tertiary venation percurrent; tertiary vein fabric opposite and straight to alternate; tertiary vein angle obtuse; quaternary vein fabric appears reticulate and regular. Tooth spacing regular, 1 order of teeth, spinose, sinus shape rounded, tooth shape concave-straight to flexuous-flexuous.

\section{Material examined. RBCM P1512, P1513.}

Re marks. Two specimens from the Red Lake collections (Pl. 4, figs 1, 2) are a good match for Castanea spokanensis (Chaney and Axelrod, 1959: Pl. 24, figs 8, 9), a species known from the middle Miocene Sucker (Succor) Creek, Trout Creek (Graham, 1963) and White Bird macrofloras (Chaney and Axelrod, 1959). 
Baghai and Jorstad (1995) recorded Castanea as part of the late middle Miocene Musselshell Creek flora, Idaho. The distinctive spinose teeth (Pl. 4, fig. 2) and widely spaced pinnate secondary venation of this taxon ("deeply scalloped margin ... numerous secondaries which diverge at moderately high angles"; Chaney and Axelrod, 1959: p. 163) are distinctive and well preserved on the two incomplete specimens from Red Lake. Chaney and Axelrod (1959) noted a close similarity between this species and the leaves of the living American chestnut, Castanea dentata (Marsh.) Borkh. of the Appalachian Mountains of eastern USA. Specimen P1513 shows evidence of insect feeding damage. Castanea is known from several Miocene floras from the Pacific Northwest, including Trout Creek (OR), Musselshell Creek (ID), Succor Creek (OR-ID), and White Bird (WA) (Tab. 1).

Genus: Fagus L., 1753

\section{Fagus pacifica Chaney}

Pl. 4, fig. 3

Description. Leaf attachment petiolate, laminar size microphyll $(\sim 8 \times 2.6 \mathrm{~cm} ; n=1)$, laminar shape elliptic, margin serrate. Apex angle acute, apex shape straight; base angle acute, base shape cuneate. Primary venation pinnate; agrophic veins absent; secondary venation craspedodromous; secondary vein spacing uniform; secondary vein angle uniform; secondary vein attachment to midvein excurrent; intersecondary veins absent; tertiary vein fabric percurrent, opposite; tertiary vein courses straight to convex. Tooth spacing regular, 1 order of teeth, sinus rounded, tooth shape concave-flexuous to flexuous-straight.

\section{Material examined. RBCM P1514.}

Remarks. This leaf (Pl. 4, fig. 3) matches Fagus pacifica (Chaney, 1927) from Whitebird (Idaho) as illustrated without further description by Berry (1934: Pl. 20, fig. 1). This taxon was synonymized as $F$. washoensis Lamotte by Chaney and Axelrod (1959); however, the specimens they illustrated from the Blue Mountains and Mascall (Chaney and Axelrod, 1959: Pl. 25, figs 7-10) lack the apiculate teeth seen in the specimens illustrated by Berry (1934) and also found on the Red Lake specimens. Fagus washoensis includes specimens from some floras misidentified as Ulmus speciosa, Quercus spokanensis Knowlton and other unrelated taxa (Chaney and Axelrod, 1959). Fagus is widely reported for Miocene floras from the Pacific Northwest and was also reported from the St. Eugene silts flora and Quesnel (BC) (Tab. 1).

Family: Betulaceae Gray, 1822

Genus: Alnus Mill., 1754

Alnus harneyana Chaney et Axelrod

Pl. 4 , fig. 4

Description. Leaf attachment petiolate, laminar size notophyll $(8.5 \times \sim 5 \mathrm{~cm} ; n=1)$, leaf shape incomplete, margin serrate. Apex angle acute, apex shape straight; base angle obtuse, base shape truncate. Primary venation pinnate; agrophic veins absent; secondary venation craspedodromous; secondary vein spacing decreasing proximally; secondary vein angle gradually decreasing proximally; secondary vein attachment to midvein proximally decurrent. Tooth spacing regular, 2 orders of teeth, sinus rounded, tooth shape convex-concave.

Material examined. RBCM P1516.

Remarks. The specimen from Red Lake (Pl. 4, fig. 6) is a good match for A. harneyana as illustrated in Chaney and Axelrod (1959: Pl. 21, figs 4-9), so this species is identified from the Red Lake flora. Chaney and Axelrod (1959: p. 158) differentiated between Alnus and Betula as follows: "(a) the leaves of Alnus are characterized by strong subsecondaries which diverge from the abaxial side of the secondaries in the outerpart of the blade, whereas if subsecondaries are present in Betula they are only weakly developed; (b) in leaves of comparable size, Betula has more numerous and more closely spaced secondaries than Alnus; (c) in shape Alnus is generally wider in the lower half of the blade, not near the middle of the blade like Betula; (d) the marginal outline is more even in Betula than in Alnus." Alnus harneyana was listed without description or illustration by Mathews and Rouse (1963) and Rouse and Mathews (1979) from Miocene floras of the "late Tertiary lavas" and also the Crownite Formation. Alnus is widely reported from Micoene floras across the Pacific Northwest (Tab. 1). 

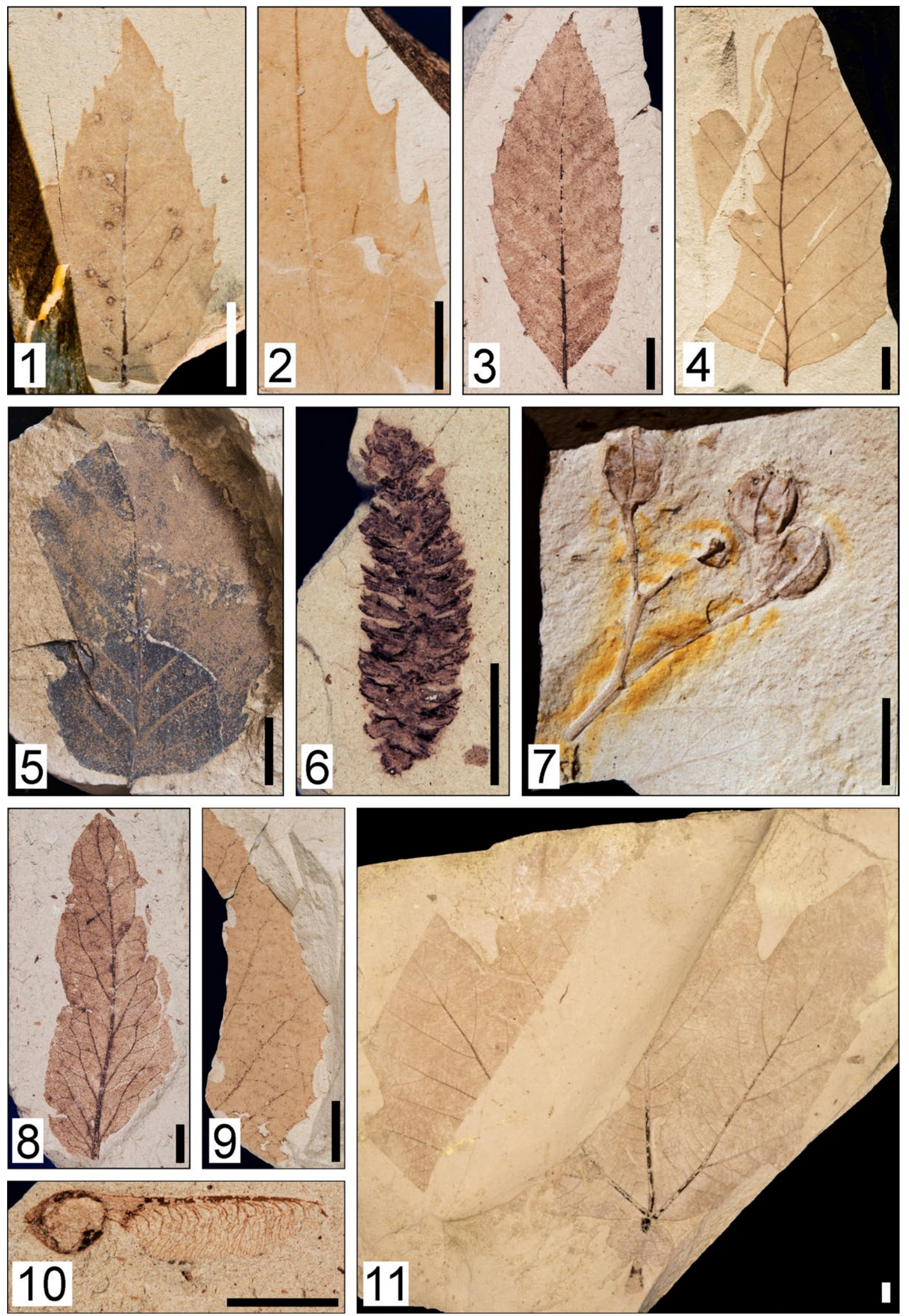

Plate 4. 1, 2. Castanea spokanensis (Knowlton) Chaney et Axelrod, 1. leaf, showing acute apex and serrate margin, RBCM P1513, 2. enlarged view of sharply acute serrate teeth, RBCM P1512; 3. Fagus pacifica Chaney, RBCM P1514; 4. Alnus harneyana Chaney et Axelrod, RBCM P1516; 5. Betula thor Knowlton, TRUIPR L-053 F-001; 6. Betula sp. infructescence, RBCM P1532; 7-9. Tilia pedunculata Chaney, 7. cymose infructesence with fruits, TRUIPR L-053 F-016, 8. pinnately veined leaf-like bract referred to Tilia pedunculata Chaney, RBCM P1518, 9. leaf fragment with margin and venation characters similar to leaves of Tilia sp., RBCM P1540; 10. Acer aff. A. brownii Wolfe et Tanai, samara, RBCM P1519; 11. Acer sp. leaf, RBCM P1520. Scale bars = $1 \mathrm{~cm}$ 
Genus: Betula L. 1753

\section{Betula thor Knowlton}

Pl. 4, fig. 5

Description. Leaf attachment petiolate, laminar size microphyll $(\sim 5.5-6 \times \sim 4-5 \mathrm{~cm}$; $n=2$ ), laminar shape ovate to round, margin crenately serrate. Apex angle acute, apex shape straight; base angle obtuse, base shape truncate to weakly cordate. Primary venation pinnate; simple agrophic veins present; secondary venation craspedodromous; secondary vein spacing uniform; secondary vein angle abruptly increasing proximally; secondary vein attachment to midvein excurrent; interscondary veins absent. Tooth spacing regular, 2 orders of teeth, sinus rounded, tooth shape convex-convex.

Material exa mined. TRUIPR L-053 F-001; RBCM P1517.

Remarks. The Red Lake specimens are a match for Betula thor, which are characterized by their small size and serrate margins (Chaney and Axelrod, 1959). The species Betula thor was recognized by Mathews and Rouse (1963) from the "late Tertiary lavas", and the Red Lake specimens are a good match for the illustrations of this species in Chaney and Axelrod (1959: Pl. 23, figs 2-6). Betula is widely reported from Miocene floras across the Pacific Northwest (Tab. 1).

\section{Betula sp. \\ Pl. 4, fig. 6}

Description. Infructescence, $3 \mathrm{~cm}$ in length, $0.9 \mathrm{~cm}$ wide; base rounded or obtuse; apex not preserved; composed of numerous trifid bracts $\sim 4-5 \mathrm{~mm}$ long $(n=3)$ arranged on central axis in $\sim 18$ whorls.

\section{Material examined. RBCM P1532.}

Remarks. This specimen was described from a single incomplete specimen, and the shape and numerous whorled bracts suggest this fossil is an infructescence comparable to that of Betula, Corylus or another member of the Betulaceae. Trilobed bracts are diagnostic of Betula (Crane and Stockey, 1987; e.g., Betula alleghaniensis Britt.), however. An infructescence comparable to RBCM P1532, with crowded trifid bracts, is found in the Eocene species Betula leopoldae (Crane and Stockey, 1987: see fig. 16), described from leaves, catkins, pollen, seeds and whole infructescences.

\section{Rosids / Malvids}

Order: Malvales

Juss. ex Bercht. et J.Presl, 1820

Family: Malvaceae Juss., 1789

Genus: Tilia L., 1754

\section{Tilia pedunculata Chaney}

Pl. 4, figs 7-9

Description. A cymose infructescence with three subglobose to short-oblong fruits $\sim 0.8-1.0$ $\times 0.6-0.8 \mathrm{~cm}(n=3)$ with longitudinal sutures. A pinnate-veined "leaf" adjacent to the base of the cyme's stalk appears to be a bract attached to the peduncle. A separate leaf-like bract is notophyll-sized $(9 \times 3.2 \mathrm{~cm}, n=1)$, ovate-lanceolate, with untoothed margin; primary venation pinnate; secondary venation brochidodromous, with the secondary veins showing an irregular course; apex convex; base asymmetric, convex on one side and cuneate on the other.

Material examined. TRUIP L-053 F-016 (cymose fruits); RBCM P1518 (bract).

Remarks. Infructescences of Tilia and isolated bracts from Tilia infructescences are commonly found in Miocene floras from western North America (Manchester, 1994). Unfortunately, specimen L-053 F016 (Pl. 4, fig. 7) does not preserve the position of attachment of the bract and peduncle, so the relative length and character of attachment of the stalk, and the proportion of the peduncle below the point of attachment to the bract, are unknown. However, a pinnate-veined leaf-like bract on a cyme bearing subglobose fruits is diagnostic of Tilia Type B and Type C of Manchester (1994). An isolated leaf (P1518; Pl. 4, fig. 8) with brochidodromous secondary venation, with an irregular course and lamina shape, resembles examples of isolated fossil Tilia bracts of Type B illustrated by Manchester (1994: figs 13, 14, 22) and also the extant species T. endochrysea Hand.Mazz. (cf. fig. 25 in Manchester, 1994). Manchester (1994) noted that it is difficult to identify fossil Tilia infructescences to species when based on bract venation without attachment 
information, and the Red Lake specimen lacks any evidence of an attachment by the peduncle; however, the presence of prominent longitudinal sutures on a smooth fruit surface - as seen in L-053 F016 - is found in extant Asian species such as T. endochrysea (Manchester, 1994; Pigott, 2006). The late Eocene-Miocene North American species $T$. pedunculata Chaney was defined by Manchester (1994) as including all specimens with a Type B infructescence, and the Red Lake specimens are included within this concept. Tilia is reported from the Trout Creek and Succor Creek floras in Oregon, and was also reported for the St. Eugene silts flora (Tab. 1).

\section{cf. Tilia}

Pl. 4, fig 9

Description. Leaf fragment, laminar size unknown, laminar shape unknown; primary venation unknown; secondary venation poorly preserved, but vein course and termination suggest a semicraspedodromous vein framework; tertiary vein fabric percurrent; tertiary vein course alternate. Tooth spacing regular, 1 order of teeth, sinus rounded, tooth shape concave-convex to concave-straight.

\section{Material examined. RBCM P1540}

Re m arks. This leaf fragment from the USPC collection bears teeth and secondary venation consistent with Tilia but lacks sufficient diagnostic characters to be referred to Tilia.

\section{Order: Sapindales \\ Juss. ex Bercht. et J.Presl, 1820}

Family: Sapindaceae Juss., 1789

Genus: Acer L., 1753

Acer aff. A. brownii Wolfe et Tanai (samara)

$$
\text { Pl. 4, fig. } 10
$$

Description. Samara $\sim 3 \mathrm{~cm}$ in length and $0.5 \mathrm{~cm}$ wide, with basal, nearly circular nutlet $0.6-0.7 \mathrm{~cm}$ across; nutlet markedly inflated and smooth. Attachment scar $\sim 0.4 \mathrm{~cm}$; attachment angle $\sim 42^{\circ}$. Distal keel of nutlet rounded. Sulcus shallowly curved, with abrupt connection to nutlet. Wing oblong, narrowing to rounded apex; veins diverging at $24-35^{\circ}(n=4)$, sharply curving and extending in irregular to straight course distally, bifurcating, with few vein anastomoses.

\section{Material examined. RBCM P1519.}

Re m arks. Mathews and Rouse (1963) reported an Acer from the "late Tertiary lavas" but did not specify whether this record was a leaf or a samara, although Dawson (1883: p. 33) reported Acer leaves from the Quesnel River "along with many nuts and fruits probably belonging to the same species (as) some of the leaves". Wolfe and Tanai (1987) described samaras of Acer busamarum ssp. fingerrockense Wolfe et Tanai, A. minutifolium Chaney and A. traini Wolfe et Tanai, and leaves of Acer medianum Knowlton and A. minutifolium, from a site they listed as "early Miocene, Chilcotin River" (GSC pl. loc. 5786) but that Bolton (1994) lists as "Miocene, Hanceville, BC" (Fig. 1). Basalts of the Chilcotin Group at Hanceville are upper Middle to Upper Miocene (K-Ar 13-7.9 Ma, Mathews, 1989; see fig. 1 herein). The samaras of $A$. busamarum ssp. fingerrockense are large $(4.6-8.1 \mathrm{~cm}$, typically $6.3 \mathrm{~cm}$ ), double the size of the Red Lake samara (Pl. 4, fig. 7), whereas the samara of A. traini is of a length $(1.2-2.5 \mathrm{~cm})$ comparable to the Red Lake specimen but is much broader and has a triangular nutlet. The Red Lake specimen is similar in size to A. smileyi Wolfe et Tanai (samaras 1.8-2.2 cm long, 0.8$0.9 \mathrm{~cm}$ wide; nutlets $0.7-1.0 \mathrm{~cm}$ long, $0.5-0.6 \mathrm{~cm}$ wide) but the latter species has non-circular nutlets and a lower attachment angle for the nutlets (30-50 in A. smileyi). Samaras of Acer brownii (Wolfe and Tanai, 1987: Pl. 34, fig. 6) from Clarkia (ID) and the Skonun flora (Fig. 1) are a good match for the Red Lake specimen, however, with samaras of a comparable sulcus and wing shape and length, although narrower (A. brownii; $2.5-3.0 \mathrm{~cm}$ long, $1.0-1.2 \mathrm{~cm}$ wide) and with a circular but larger nutlet (A. brownii; nutlet $0.8-1.0 \mathrm{~cm}$ long, $0.7-0.8 \mathrm{~cm}$ wide), and wing veins that are straighter than the Red Lake specimen. Acer - as samaras or leaves - is widely reported from Miocene floras of the Pacific Northwest (Wolfe and Tanai, 1987) (Tab. 1).

\section{Acer sp. (leaf) \\ Pl. 4, fig. 11}

Description. Leaf attachment petiolate, laminar size mesophyll, laminar shape incomplete, trilobed; margin untoothed to crenately 
dentate. Lobe apex angle acute, lobe apex shape straight; base angle obtuse, base shape round to weakly cordate. Primary venation actinodromous; compound agrophic veins present; secondary venation semicraspedodromous; secondary vein spacing uniform; secondary vein angle smoothly increases proximally; secondary venation attachment to midvein excurrent; intersecondary veins absent; tertiary venation percurrent; tertiary vein fabric opposite and convex; tertiary vein angle variable; exterior tertiary vein course variable; quaternary venation percurrent, opposite to alternate. Tooth distance irregular, 1 order of teeth present, sinus rounded, tooth shape convex-convex.

Material examined. RBCM P1520 - part and counterpart.

Remarks. Wolfe and Tanai (1987) examined a wide range of Acer leaf species from the Cenozoic of North America, including the Miocene species $A$. medianum and A. minutifolium from "Chicoltin" in British Columbia (Hanceville of Mathews and Rouse, 1979; Bolton, 1994), and several other Miocene leaf taxa from the adjoining areas of the Pacific Northwest. The Red Lake specimen is not a match for A. medianum or A. minutifolium, as these species have small leaves with deep sinuses, and A. medianum has prominent and closely spaced, pointed compound teeth in contrast to the sparse blunt simple teeth of the Red Lake specimen ( $\mathrm{Pl}$. 4, fig. 5). However, the leaf species Acer bolanderi Lesq. (Table Mountain, CA), A. schornii Wolfe et Tanai (e.g., Fingerrock and Trout Creek as a leaf specimen) and A. whitebirdense (Ashlee) Wolfe et Tanai (Whitebird, Baker and Stinking Water as a leaf specimen) share with the Red Lake specimen a similar base, shallow sinuses between the lobes, and few, widely spaced, blunt teeth on each lobe, including 1-3 basal teeth on each of the lateral lobes. Wolfe and Tanai (1987) noted that the late Miocene species A. schorni is strongly similar to $A$. bolanderi but that A. schorni is typically 5-lobed, with two teeth on the basal sides of the lateral lobes (vs. 1 in A. bolanderi and 1-3 in A. whitebirdense), with small areoles, whereas $A$. bolanderi - from the early to late Miocene of California - is 3-lobed and has large areoles, the arrangement seen in the Red Lake specimen. Acer whitebirdense is comparable in size to the Red Lake specimen $(7-20 \mathrm{~cm} \times 7-29 \mathrm{~cm}$ vs. $\sim 20 \times>20 \mathrm{~cm})$ but is always 5-lobed, with 1-3 teeth on the basal side of the lateral lobes, whereas A. bolanderi (2-6 $\times 2.5-6 \mathrm{~cm})$ and A. schorni $(3.2-7 \times 3.5-10 \mathrm{~cm})$ are much smaller than the Red Lake specimen.

Acer schorni was noted by Wolfe and Tanai (1987: p. 180) as resembling in many respects the extant species A. saccharum Marsh (sugar maple). The leaves of $A$. saccharum are trilobed, with sparse teeth that may rarely be rounded but typically are much more pointed, with deeper sinuses between the central and lateral lobes than seen in the Red Lake specimen. Two other extant species, A. floridanum (Chapm.) Pax and A. leucoderme Small from the southeastern US, have sparse blunt teeth but also are typically 5-lobed, although the lowermost pair may be quite reduced yet retaining a discernible primary lobe vein, a feature lacking in the Red Lake specimen. A common extant species in coastal British Columbia with large leaves comparable in size to the Red Lake specimen is the bigleaf maple, Acer macrophyllum Pursh (8-15 cm × 10-30 cm). Bigleaf maple normally has five lobes, and the lobes are sparsely toothed and very similar in appearance to those of the Red Lake specimen, but some leaves of $A$. macrophyllum appear to be 3-lobed due to the lowermost pair of lateral lobes being very small and with a weak primary vein, and the overall appearance of these "3-lobed" forms suggests affinity to the Red Lake specimen, with the exception of the sinuses being shallower in the fossil, with only three lobes. No specific affinity is assigned for this specimen.

Eudicots, incertae sedis

Fossil-genus: Dicotylophyllum Saporta, 1892

\section{Dicotylophyllum sp. 1}

Pl. 5, fig. 1

Description. Leaf attachment petiolate, laminar size microphyll $(\sim 4.2 \times \sim 3.4 \mathrm{~cm}, n=1)$, laminar shape ovate, basally lobed, margin not preserved. Apex not preserved; base angle obtuse, base shape round. Primary venation pinnate; agrophic veins not observed; secondary venation craspedodromous, with $\sim 4-5$ secondary veins that extend toward margin; secondary vein spacing abruptly increases proximally; secondary vein angle uniform; secondary vein attachment to midvein excurrent; weak intersecondary veins present, extending 

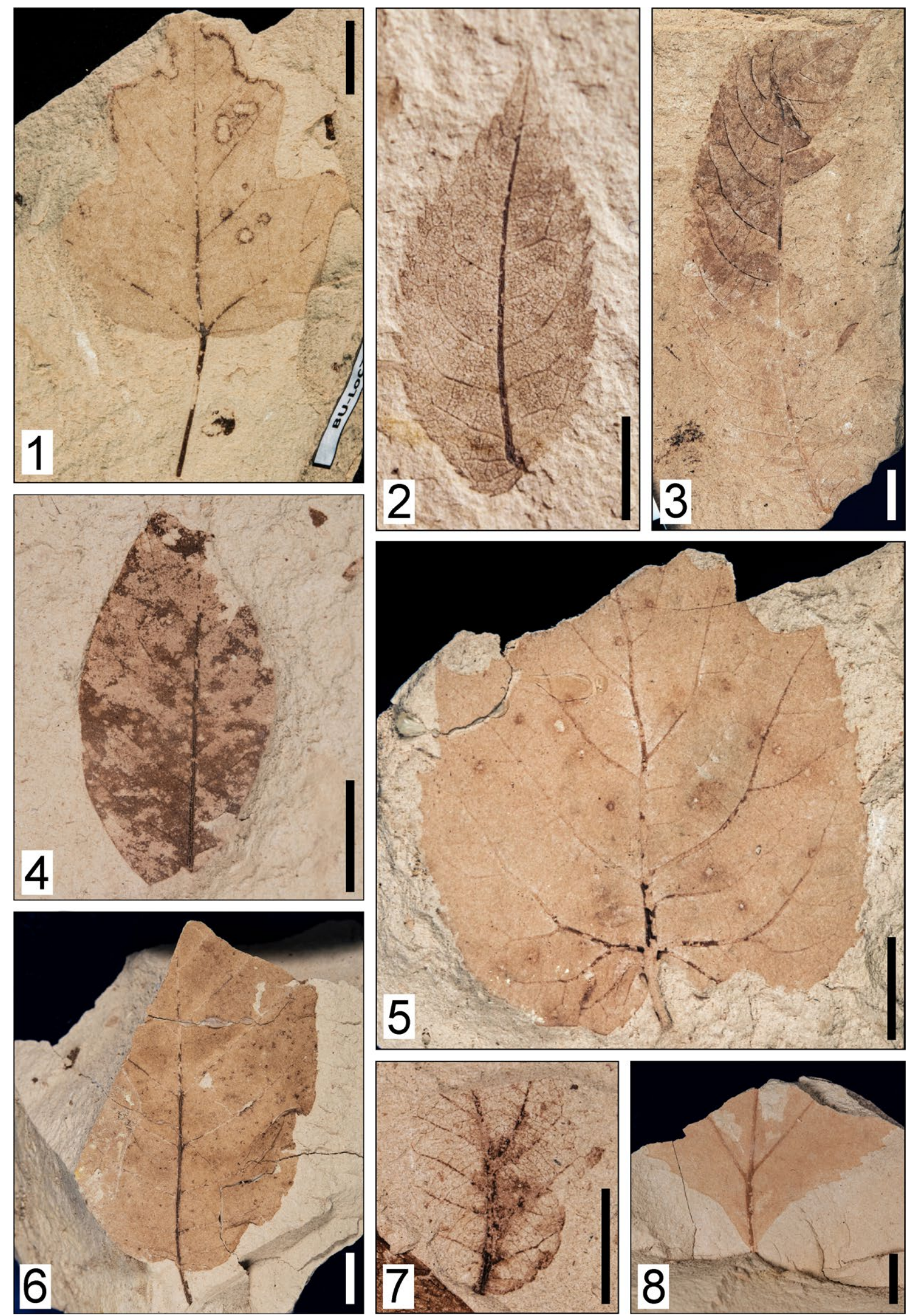

Plate 5. 1. Dicotylophyllum sp. 1, RBCM P1521; 2. Dicotylophyllum sp. 2, TRUIPR L-053 F-003; 3. Dicotylophyllum sp. 3, RBCM P1523; 4. Dicotylophyllum sp. 4, RBCM P1525; 5. Dicotylophyllum sp. 5, RBCM P1526; 6. Dicotylophyllum sp. 6, RBCM P1527; 7. Dicotylophyllum sp. 7, RBCM P1528; 8. Dicotylophyllum sp. 8, RBCM P1529. Scale bars $=1 \mathrm{~cm}$ 
towards sinuses of basal lobes before branching to loop around into a secondary vein; tertiary venation percurrent; tertiary vein fabric alternate; tertiary vein angle obtuse; quaternary vein fabric appears reticulate, regular.

\section{Material examined. RBCM P1521.}

Rem arks. The general shape of this leaf, as well as the presence of branching intersecondary veins reaching towards a lobal or dental sinus, can be diagnostic for Acer (Wolfe and Tanai, 1987); however, the specimen's poor preservation and lack of additional diagnostic characters prevent assignment to Acer.

\section{Dicotylophyllum sp. 2}

Pl. 5, fig. 2

Description. Leaf attachment petiolate, laminar size microphyll $(\sim 3.9 \times \sim 1.9 \mathrm{~cm}$, $n=1$ ), laminar shape elliptic, margin serrate. Apex angle acute, apex shape straight; base angle obtuse, base shape asymmetrically rounded. Primary venation pinnate; agrophic veins absent; secondary venation semicraspedodromous; secondary vein spacing uniform; secondary vein angle uniform; secondary vein attachment to midvein excurrent; rare weak intersecondary veins present; tertiary vein fabric percurrent, tertiary vein course straight. Tooth spacing regular, 1 order of teeth, sinuses rounded, tooth shape straight-flexuous.

Material examined. TRUIPR L-053 F-003.

Remarks. Described from a single specimen, this fossil possesses an asymmetric base, a robust serrate margin and prominent semicraspedodromous venation. This specimen appears to be superficially similar to leaves assigned to Ulmus, but the strongly looped semicraspedodromous venation suggests Rosaceae. The limited material available for study prevents this fossil leaf from being given a taxonomic assignment.

\section{Dicotylophyllum sp. 3}

Pl. 5, fig. 3

Description. Leaf attachment not preserved, laminar size mesophyll $(\sim 11 \times \sim 3.8 \mathrm{~cm}$, $n=1$ ), laminar shape elliptic, margin serrate or crenately serrate. Apex angle acute, apex shape acuminate or straight; base not preserved. Primary venation pinnate; agrophic veins absent; secondary venation semicraspedodromous; secondary vein spacing uniform; secondary vein angle uniform; secondary vein attachment to midvein excurrent; intersecondary veins absent; intercostal tertiary vein fabric percurrent, opposite; tertiary vein course straight to sinuous. Tooth spacing regular, 1 order of teeth, sinuses rounded, tooth shape convex-convex to concave-convex.

\section{Material examined. RBCM P1523.}

R e m arks. The elliptic leaf shape, semicraspedodromous secondary venation and finely serrate to crenately serrate margin of this fossil leaf suggest an affinity to Aesculus or Carya; however, the poor preservation of this specimen prevents assignment to a genus.

Dicotylophyllum sp. 4

Pl. 5, fig. 4

Description. Leaf attachment not preserved, laminar size microphyll, laminar outline incomplete, margin untoothed. Apex shape and angle not preserved; base shape and angle not preserved. Primary venation pinnate; secondary venation brochidodromous; secondary vein spacing gradually increases proximally; secondary vein angle uniform; secondary vein attachment to midvein excurrent; intersecondary veins absent; tertiary vein fabric not preserved.

Material examined. RBCM P1524, P1525.

Remarks. Untoothed leaves are rare within the Red Lake flora. As this fossil was described from two incomplete specimens, a firm taxonomic assignment is precluded.

Dicotylophyllum sp. 5

Pl. 5, fig. 5

Description. Leaf attachment petiolate, laminar size notophyll, laminar shape ovate, weakly lobed, margin serrate. Apex not preserved; base angle reflexed, base shape cordate. Primary venation pinnate; simple agrophic veins present; secondary venation craspedodromous; secondary vein spacing irregular; secondary vein angle smoothly decreasing proximally; secondary vein attachment to midvein excurrent; intersecondary veins present; tertiary vein fabric percurrent, opposite; tertiary vein course straight. Tooth spacing regular, 
1 order of teeth, sinuses rounded, tooth shape concave-convex.

\section{Material examined. RBCM P1526.}

R e m a rks. This fossil leaf has structural similarities to leaves assigned to Vitaceae from the Miocene of Florida (i.e., Lott et al., 2019), but the material available for study is too limited to permit an assignment to the Vitaceae.

\section{Dicotylophyllum sp. 6}

Pl. 5, fig. 6

Description. Leaf attachment petiolate, laminar size notophyll, laminar outline incomplete, margin serrate. Apex not preserved; base incomplete. Primary venation pinnate; agrophic veins absent; secondary venation semicraspedodromous; secondary vein spacing gradually decreasing proximally; secondary vein angle smoothly increasing proximally; secondary vein attachment to midvein proximally decurrent; intersecondary veins not observed; tertiary vein fabric not preserved. Tooth distance irregular, 1 order of teeth, tooth sinus weakly rounded, tooth shape straight-concave.

Material examined. RBCM P1527.

R e m a r k s. The distantly spaced, small, sharply serrate teeth preserved on this fossil specimen do not align with any other specimens described from the Red Lake flora. As this specimen was described from a single damaged specimen, no taxonomic assignment is offered.

\section{Dicotylophyllum sp. 7}

Pl. 5, fig. 7

Description. Leaf attachment petiolate, laminar size microphyll, laminar outline incomplete, margin not preserved. Apex not preserved; base angle obtuse, base shape rounded. Primary venation pinnate; agrophic veins absent; secondary venation semicraspedodromous or brochidodromous; secondary vein spacing uniform; secondary vein angle uniform; secondary vein attachment to midvein excurrent; intersecondary veins absent; tertiary vein fabric percurrent, opposite; tertiary vein course straight.

Material examined. RBCM P1528.

Remarks. The suite of architectural characters observed on this specimen separate it from other taxa identified from the Red Lake flora. This fossil was described from a single fragmentary specimen, so a firm taxonomic assignment is not provided.

\section{Dicotylophyllum sp. 8}

$$
\text { Pl. 5, fig. } 8
$$

Description. Leaf attachment petiolate, leaf size not observed, laminar shape not observed, margin serrate. Apex not preserved; base angle acute, base shape decurrent. Primary venation pinnate or palinactinodromous; agrophic veins present; major secondary venation not preserved. Tooth spacing regular, 1 order of teeth, sinuses rounded, tooth shape concave-convex.

Material examined. RBCM P1529.

Rem arks. Although fragmentary, with poorly preserved secondary venation, the architectural characters present on this specimen suggest this fossil is a taxon distinct from others at Red Lake. The serrate margin and palinactinodromous venation suggest similarity to Platanus dissecta. This similarity is further reinforced by the presence of offset major veins branching from the midvein, and agrophic veins branching out towards the margin, and suggesting that this specimen may be Platanus dissecta; however, due to its fragmentary preservation this specimen remains unidentified.

\section{Dicotylophyllum sp. 9}

Pl. 6, fig. 1

Description. Leaf attachment not preserved, laminar size mesophyll $(\sim 8 \times \sim 10 \mathrm{~cm}$, $n=1$ ), laminar shape ovate, 5-lobed, margin untoothed but rare single teeth sometimes present. Apex not preserved; base angle obtuse, base shape truncate. Primary venation actinodromous; agrophic veins present; secondary venation semicraspedodromous or brochidodromous; secondary vein spacing gradually increasing proximally; secondary vein angle uniform; secondary vein attachment to midvein excurrent; intersecondary veins absent; tertiary venation percurrent; tertiary vein fabric alternate; tertiary vein angle obtuse; exterior tertiary vein course variable.

Material examined. RBCM P1530.

R e m arks. This fossil specimen does not align with Platanus dissecta or Acer, despite sharing 

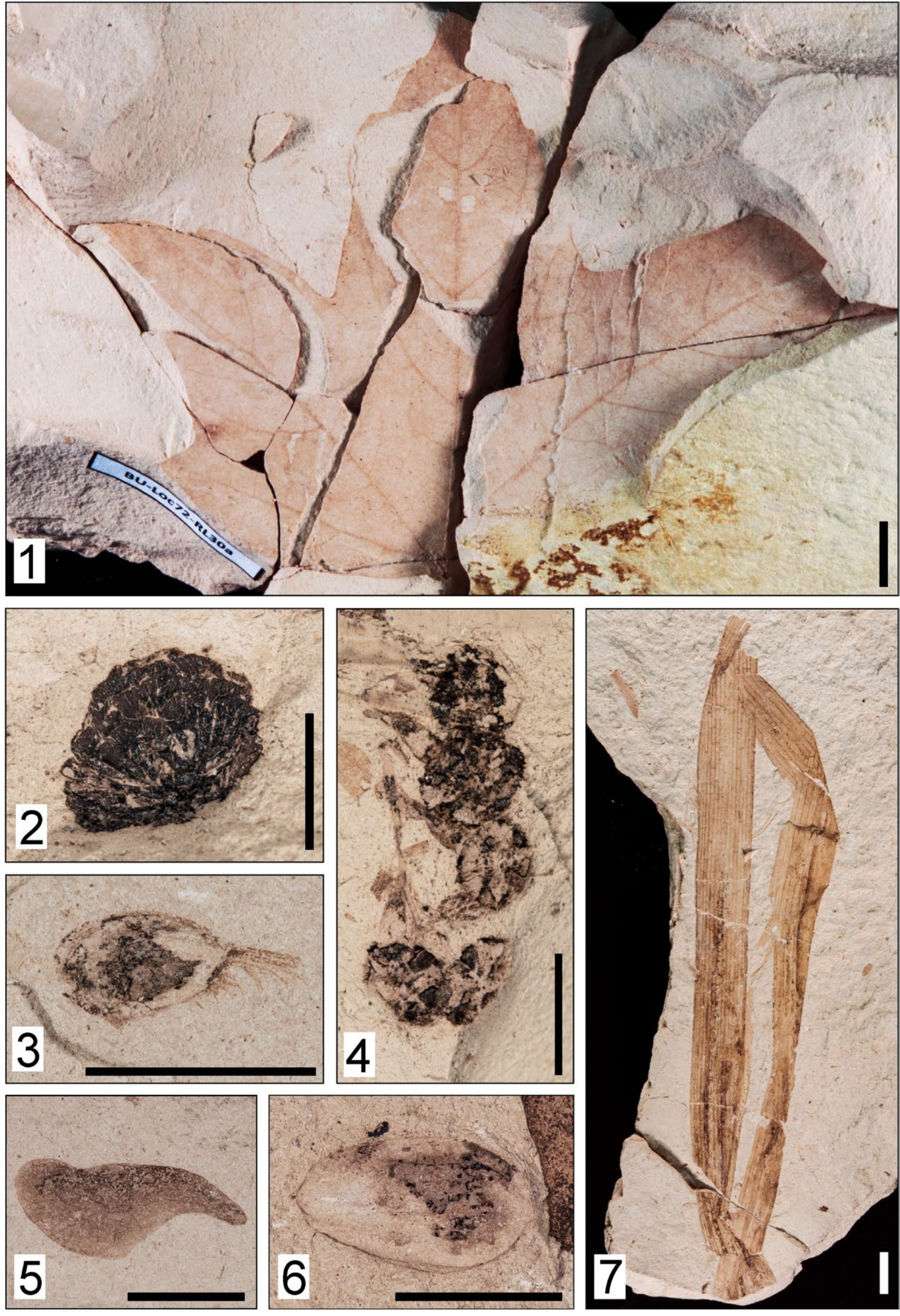

Plate 6. 1. Dicotylophyllum sp. 9 , RBCM P1530; 2. unidentified fruit or seed 1, RBCM P1515; 3. unidentified fruit or seed 2, RBCM P1531; 4. unidentified infructescence, RBCM P1533; 5. unidentified fruit or seed 3, RBCM P1534; 6. unidentified fruit or seed 4, RBCM P1535; 7. Monocotylophyllum sp., RBCM P1536. Scale bars $=1 \mathrm{~cm}$ 
architectural similarities (e.g., five lobes and actinodromous venation). The style of the lobing and venation are suggestive of Liquidambar; however, the specimen has only sparse teeth preserved, whereas Liquidambar leaves have margins with prominent, closely spaced, upward-pointing teeth. As this fossil was described from a single damaged specimen, we do not offer a firm taxonomic assignment here.

\section{Incertae sedis}

\section{Unidentified fruit or seed 1.}

Pl. 6, fig. 2

Description. Exocarp, or nut, surface winkled or scaly, orbicular in outline, $16 \mathrm{~mm}$ wide, $12 \mathrm{~mm}$ deep $(n=1)$.

Material examined. RBCM P1515.

Remarks. We do not provide a taxonomic assignment.

\section{Unidentified fruit or seed 2.}

$$
\text { Pl. 6, fig. } 3
$$

De s c ription. Seed or fruit (?achene), $7.6 \mathrm{~mm}$ long, 4.9 wide $(n=1)$, ovoid to weakly elliptic, apex acute, base rounded; cluster of $\sim 20$ hairs on apical end.

\section{Material examined. RBCM P1531.}

Re marks. The cluster of hairs present on the distal (apical) end of this seed or fruit separate this fossil from other fossils found in the Red Lake flora. However, the size and shape of the main body of the seed or fruit is similar to the nutlet of a small Acer samara, so the distal "hairs" may represent vasculature from a decayed wing.

Unidentified infructescence.

$$
\text { Pl. 6, fig. } 4
$$

Description. Racemose infructesence with 5 fruits; individual fruits valvate, $6-9 \mathrm{~mm}$ in diameter $(n=5)$; valves triangular, number of valves per fruit indeterminate, but $\sim 5-6$.

\section{Material examined. RBCM P1533.}

Re marks. This specimen was described from a single poorly preserved specimen and as such the taxonomic affinity remains unresolved.

\section{Unidentified fruit or seed 3.}

Pl. 6, fig. 5

Description. Seed $2 \mathrm{~cm}$ long, $0.8 \mathrm{~cm}$ wide at widest point $(n=1)$; body of seed elliptical, with notch on distal edge; apex rounded, narrowing to curved rounded tip.

Material examined. RBCM P1534.

Remarks. The fossil represents a seed that is strongly hook-shaped in outline, broadly rounded and robust, and eventually narrowing into a rounded base or tip. These features distinguish it from other seeds in the Red Lake flora. No taxonomic assignment is attempted here, due to a lack of diagnostic features.

Unidentified fruit or seed 4.

Pl. 6, fig. 6

Description. Seed, $1.4 \mathrm{~cm}$ long, $\sim 0.8 \mathrm{~cm}$ wide $(n=1)$, ovoid; apex and base rounded.

Material examined. RBCM P1535.

Remarks. Although poorly preserved, this specimen appears to be an impression of an ovoid seed or nut, with possible internal structure or mass present. The size and general ovoid shape of the seed or nut is comparable to a small acorn (Quercus spp.), but lacks definitive diagnostic features (such as the cup) for a taxonomic assignment.

\section{Monocots}

Order: cf. Poales Small, 1903

Fossil-genus: Monocotylophyllum Reid et Chandler 1926

\section{Monocotylophyllym sp.}

Pl. 6, fig. 7

Description. Linear leaf fragments up to $30 \mathrm{~cm}$ long and $0.8-1.3 \mathrm{~cm}$ wide $(n=3)$, showing prominent parallel venation. Veins all of equal size, with cross veins generally straight and at right angles to the main veins and forming a rectangular pattern of veins parallel to the long axis of the leaf. Margin entire.

Material examined. RBCM P1536, P1537.

Remarks. These linear leaf fragments (Pl. 5, fig. 5) likely represent sedges, reeds 
or rushes (Cyperaceae, Juncaceae or Typhaceae) in lakeside vegetation. In general form these fragments correspond to Cyperacites sp. from the Mascall flora (Knowlton, 1902: Pl. 1, fig. 9), a catch-all taxon for similar specimens described from several Miocene floras (e.g., Chaney and Axelrod, 1959). Similar material has also been assigned to Poacites, Phragmites and other genera. Wolfe and Tanai (1980) referred comparable material - fragmentary linear leaves with many parallel veins - from the Miocene Seldovia Point flora (Alaska) to Monocotylophyllum in recognition of the absence of diagnostic features in such leaves permitting assignment to a family or genus, a practice we follow here.

\section{PALAEOCLIMATE}

The palaeoclimate of Red Lake was reconstructed using leaf physiognomy as mesic (relative humidity $83 \pm 8.6 \%$ ), with a mean annual precipitation of $170-51 /+73 \mathrm{~cm} / \mathrm{yr}$, estimated from leaf area analysis (LAA), and growing season precipitation (GSP) of $92 \pm 32 \mathrm{~cm}$ for a growing season length of $7.1 \pm 1.1$ months, with precipitation of $51 \pm 23 \mathrm{~cm}$ during the three wettest months (3-WET) vs. $25 \pm 6 \mathrm{~cm}$ during the three driest months (3-DRY), (Tabs $3,4)$. The mean annual temperature (MAT) was estimated at $11.8 \pm 2.1^{\circ} \mathrm{C}$ using CLAMP and at $10.3 \pm 3.1^{\circ} \mathrm{C}$ from leaf margin analysis (LMA), with warm month mean temperature
(WMMT) of $21.3 \pm 2.5^{\circ} \mathrm{C}$ and cold month mean temperature (CMMT) of $2.6 \pm 3.4^{\circ} \mathrm{C}$ (Tabs $3,4)$. These values contrast with present-day Kamloops (elevation $345 \mathrm{~m}$ vs. Red Lake Mine $1315 \mathrm{~m}$; Fig. 2), where MAT is $8.9^{\circ} \mathrm{C}$, CMMT $-4.2^{\circ} \mathrm{C}$, WMMT $21.0^{\circ} \mathrm{C}$, three wettest months precipitation $9.4 \mathrm{~cm}$, and three driest months precipitation $1.9 \mathrm{~cm}$ (1971-2000 station data; Environment and Climate Change Canada, 2018). 100 Mile House BC is at an elevation and latitude $\left(51^{\circ} 38^{\prime} \mathrm{N}, 121^{\circ} 18^{\prime} \mathrm{W}, 1059 \mathrm{~m}\right)$ comparable to Red Lake Mine, and has MAT $4.4^{\circ} \mathrm{C}$, CMMT $7.2^{\circ} \mathrm{C}$, WMMT $15.3^{\circ} \mathrm{C}$, three wettest months precipitation $17.2 \mathrm{~cm}$, three driest months precipitation $0.7 \mathrm{~cm}$, and mean annual precipitation $32 \mathrm{~cm} / \mathrm{yr}$.

\section{DISCUSSION}

The Red Lake microflora, in contrast to the Hanceville and other microfloras from the Interior Plateau, was found by Mathews and Rouse (1963) to have lower amounts of Pinaceae pollen (Abies 1.5\%, Picea 13\%, Pinus 10\%, Tsuga 2\%, Pseudotsuga <0.5\%) and Cupressaceae s.l. absent, with conifers comprising $26.5 \%$ of the microflora (vs. 84-92.5\%). In contrast to the Red Lake's microflora, Hanceville was reported with Picea 32\%, Pinus $35 \%$ and Cupressaceae $7.5 \%$ (vs. 5.5-56\% Cupressaceae for other BC Interior Miocene microfloras). Angiosperm pollen dominated the Red Lake microflora $(62.5 \%$ vs. $3.5-9 \%$ for other BC

Table 3. Estimates of palaeoclimate for the Red Lake leaf flora using CLAMP $(n=19)$. MAT - mean annual temperature; WMMT - warm month mean temperature; CMMT - cold month mean temperature; LGS - length of growing season; GSP - growing season precipitation; MMGSP - mean monthly growing season precipitation; 3-WET - three wettest months precipitation; 3-DRY - three driest months precipitation; $\mathrm{RH}$ - relative humidity; $\mathrm{SH}$ - specific humidity; ENTHAL - enthalpy (Yang et al., 2011; 2015). Standard errors for climate parameters: MAT $\pm 2.1^{\circ} \mathrm{C}$; CMMT $\pm 3.4^{\circ} \mathrm{C}$; WMMT $\pm 2.5^{\circ} \mathrm{C}$; LGS \pm 1.1 ; $\mathrm{GSP} \pm 32 \mathrm{~cm} ; 3-\mathrm{WET} \pm 23 \mathrm{~cm} ; 3-\mathrm{DRY} \pm 6 \mathrm{~cm} ; \mathrm{RH} \pm 8.6 \% ; \mathrm{SH} \pm 1.7 \mathrm{~g} / \mathrm{kg} ; \mathrm{ENTHAL} \pm 0.8(\mathrm{~kJ} / \mathrm{kg})$

\begin{tabular}{c|c|c|c|c|c|c|c|c|c|c}
\hline \hline $\begin{array}{c}\text { MAT } \\
\left({ }^{\circ} \mathrm{C}\right)\end{array}$ & $\begin{array}{c}\text { WMMT } \\
\left({ }^{\circ} \mathrm{C}\right)\end{array}$ & $\begin{array}{c}\text { CMMT } \\
\left({ }^{\circ} \mathrm{C}\right)\end{array}$ & $\begin{array}{c}\text { LGS } \\
(\mathrm{months})\end{array}$ & $\begin{array}{c}\text { GSP } \\
(\mathrm{cm})\end{array}$ & $\begin{array}{c}\text { MMGSP } \\
(\mathrm{cm})\end{array}$ & $\begin{array}{c}3-\text {-WET } \\
(\mathrm{cm})\end{array}$ & $\begin{array}{c}3 \text {-DRY } \\
(\mathrm{cm})\end{array}$ & $\begin{array}{c}\text { RH } \\
(\%)\end{array}$ & $\begin{array}{c}\text { SH } \\
(\%)\end{array}$ & $\begin{array}{c}\text { ENTHAL } \\
(\mathrm{kJ} / \mathrm{kg})\end{array}$ \\
\hline 11.8 & 21.3 & 2.6 & 7.1 & 92 & 14 & 51 & 25 & 83 & 10 & 32.5 \\
\hline
\end{tabular}

Table 4. Estimates of mean annual temperature (MAT) and mean annual precipitation (MAP) for the Red Lake leaf flora using leaf margin analysis (LMA) and leaf area analysis (LAA), respectively. LMP - leaf margin proportion (number of morphotypes as proportion of $n: 0>X<1.0$; Wilf, 1997); MAT - mean annual temperature; MlnA - mean of the natural logarithm of leaf area; MAP - mean annual precipitation. Errors for MAP are asymmetric, as they are converted from $\log _{\mathrm{e}}$. Estimates of MAT and MAP are provided, applying alternative LMA and LAA calibrations from the listed sources

\begin{tabular}{l|c|c|c|c|l}
\hline \hline $\mathrm{n}$ & LMP & MAT $\left({ }^{\circ} \mathrm{C}\right)$ & \multirow{2}{*}{ MlnA } & MAP $(\mathrm{cm} / \mathrm{yr})$ & \multicolumn{1}{c}{ Calibration } \\
\hline 20 & 0.30 & $10.3 \pm 3.1$ & \multirow{2}{*}{7.9} & $170-51 /+73$ & Wing snd Greenwood, 1993 (LMA); Wilf et al., 1998 (LAA) \\
\cline { 5 - 6 } \cline { 5 - 5 } & & $13.1 \pm 3.7$ & & N/A & Kowalski and Dilcher, 2003 \\
\cline { 5 - 6 } & & $10.7 \pm 2.3$ & & $177-81 /+149$ & Peppe et al., 2011 (LMA \& LAA) \\
\cline { 5 - 6 } & & &
\end{tabular}


Interior Plateau Miocene microfloras), including Betulaceae (Alnus 1\%, Corylus 0.5\%), Juglandaceae (Carya 15\%; Engelhardia, Juglans, Pterocarya <1-1\%), Ilex (0.5\%), Liquidambar (0.5\%), Quercus (4\%), Salix (7\%) and abundant Ulmaceae (Ulmus and Zelkova 32\%). Tilia pollen was present in trace amounts in the Hanceville and other microfloras but was not recorded by Mathews and Rouse (1963) for Red Lake; based on the predominance of Ulmaceae and Carya in the Red Lake microflora versus the dominance of conifer in the other Interior Plateau floras, they inferred segregation of the landscape between an upland vegetation dominated by Pinaceae (e.g., Hanceville) and a broad-valley vegetation dominated by broadleaf angiosperms at Red Lake. With our present report of the associated macroflora, the relative importance of the plant taxa in the local forest can be assessed.

Mathews and Rouse (1963) and Rouse and Mathews (1979) reported macrofossils of Acer sp., Alnus (A. harneyana, A. hollandia), Betula thor, Platanus dissecta, Quercus and Ulmus speciosa from sediments associated with the Miocene basalts of Interior British Columbia, but did not provide a list of macroflora for Red Lake. The collections from Red Lake in this study contained several conifers (e.g., Metasequoia and other Cupressaceae), Alnus harneyana, Betula thor, Platanus dissecta (cf. P. youngii Graham, 1963), Quercus and Ulmus speciosa, consistent with earlier anecdotal reports for Hanceville, but adding Ginkgo, Pseudotsuga and several other angiosperms from Red Lake (Tab. 5). Additional broadleaf angiosperm taxa identified from Red Lake - Castanea spokanensis, Fagus, Liquidambar, Tilia pedunculata,
Trochodendracee (Nordenskioeldia interglacialis and Zizyphoides auriculata) - broaden the similarities between the Red Lake middle to late Miocene macroflora and contemporaneous floras from the Pacific Northwest (Tab. 5). Consistent with earlier reporting of the Red Lake microflora (Mathews, Rouse, 1963), the macroflora can best be interpreted as broadleaf deciduous forest of temperate character, which, together with genera now typical of western and eastern North American deciduous forests (e.g., Acer, Alnus, Betlua, Platanus, Quercus, Ulmus), included genera and families restricted to eastern North America (e.g., Fagus, Liquidambar, Taxodium, and Tilia) or now extinct in North America (e.g., Ginkgo, Metasequoia, and Trochodendraceae). The presence of Taxodium foliage in the Red Lake flora suggests the local presence of swamp-cypress forest.

Oaks (Quercus spp.) are represented by at least four species - including both red and white oaks - in the Red Lake flora, similar to the situation seen in several other middle to late Miocene floras regionally (Barrón et al., 2017). In addition to the leaf floras, oaks are known from fossil woods from Vantage, and a white oak is known from permineralized remains from Yakima Canyon, both sites in Washington (Wheeler and Dilhoff, 2009; Borgardt, Pigg, 1999). The late Miocene Pickett Creek (Idaho) macroflora was dominated by oak leaves of several species, principally two of the Quercus spp. (Q. columbiana $9 \%$ and $Q$. prelobata $50 \%$ in the Pickett Creek flora; Buechler et al., 2007) that are also reported here from Red Lake. The available leaf collections from Red Lake were opportunistically collected, so their relative abundance cannot be assessed,

Table 5. Key climate estimates from CLAMP for Miocene floras from the Pacific Northwest of North America (Buechler et al., 2007; Yang et al., 2011; and this study). AK, Alaska; BC, British Columbia; ID, Idaho; OR, Oregon; WA, Washington. Parameter abbreviations: see Tab. 2. *Floras with fewer than the recommended 20 leaf morphotypes

\begin{tabular}{|c|c|c|c|c|c|c|c|c|}
\hline Flora & $\mathrm{n}$ & MAT & WMMT & CMMT & LGS & GSP & 3-WET & 3-DRY \\
\hline Red Lake BC & 20 & 11.8 & 21.3 & 2.6 & 7.1 & 91.6 & 50.6 & 24.7 \\
\hline Blue Mountains OR & 28 & 7.2 & 18.1 & -3.5 & 4.9 & 40.4 & 41.2 & 19.3 \\
\hline Clarkia ID & 31 & 9.2 & 20.8 & -1.6 & 5.9 & 83.2 & 50.4 & 36.5 \\
\hline Eagle Creek OR & 30 & 10.3 & 20.9 & 0.5 & 6.4 & 91.3 & 50.3 & 28.0 \\
\hline Mascall OR & 35 & 8.7 & 19.8 & -1.7 & 5.6 & 62.1 & 37.7 & 23.2 \\
\hline Mid Ellensberg WA & 35 & 10.1 & 18.5 & 2.1 & 6.2 & 61.8 & 31.2 & 9.0 \\
\hline Pickett Ck ID & 41 & 13.4 & 24.0 & 2.8 & 7.8 & 69.0 & 21.0 & 15.0 \\
\hline Seldovia Point AK & 45 & 7.4 & 19.5 & -4.1 & 5.0 & 53.3 & 38.6 & 36.1 \\
\hline Stinking Water OR & *19 & 9.4 & 19.2 & 0.2 & 5.9 & 71.0 & 37.7 & 15.3 \\
\hline Trapper Creek ID & 27 & 8.0 & 19.1 & -2.6 & 5.4 & 68.5 & 38.2 & 19.3 \\
\hline Trout Creek ID & 34 & 8.8 & 19.1 & -1.0 & 5.8 & 95.7 & 49.0 & 22.0 \\
\hline Troutdale OR & *16 & 10.7 & 20.2 & 1.9 & 6.5 & 81.0 & 42.1 & 17.0 \\
\hline
\end{tabular}


but 3-4 taxa of oak leaves are dominant in both the Red Lake flora collections.

The Red Lake flora shares other similarities with other Miocene floras from the Pacific Northwest of North America. For example, Zizyphoides auriculata leaves, often associated with Nordenskioeldia interglacialis fruits (Trochodendraceae), are known from English Bay (Cook Inlet, Alaska), Spokane (WA), Oviatt Ck (ID), White Bird (ID), and Clarkia (ID) (Tab. 1). Acer has been identified at Red Lake from both fruit and fossil leaves and is a common element of many Miocene floras from western North America (Tab. 1). Tilia, also found at Red Lake, is another common floral element found at other Miocene fossil localities (Tab. 1). Despite sharing these common taxa across multiple Miocene fossil floras, some common floral elements are notably absent from the Red Lake fossil flora. Less common, but still present, are gymnosperms such as Ginkgo, Metasequoia and Taxodium, floral elements that are also known from similarly aged Miocene localities in western North America. Curiously, Pinus and other Pinaceae foliage are well known from these other localities (Tab. 1) but are conspicuously rare at Red Lake, with Pinus absent.

Mahonia leaves are absent in the Red Lake flora but are known from several contemporaneous macrofloras (Tab. 1). Betulaceae leaves (e.g., Alnus, Betula) appear to be rare components of the Red Lake flora, whereas in contemporaneous macrofloras they are typically more common (Tab. 1). Similarly, Ulmus appears to be a rare component of the Red Lake flora but is more common in other Miocene macrofloras from the Pacific Northwest (Tab. 1). Liquidambar is known from several Miocene fossil floras (see Tab. 1) including the Red Lake flora; however, the fossil evidence for Liquidambar from Red Lake is restricted to a single fruit, while leaves are more typically known from other floras.

Pollen of Pinaceae (26.5\%, Pinus 10\%), Betulaceae, Juglandaceae (Carya 15\%; Engelhardia, Juglans and Pterocarya $<1-1 \%$ ) and Ulmus-Zelkova (32\%) were all recorded in relatively high amounts in the Red Lake microflora (Mathews and Rouse, 1963), in contrast to the corresponding macrofloral elements, where these tree taxa are all rare or absent. In contrast, whereas Tilia and foliage of Cupressaceae - Cupressinocladus, Metasequoia and Taxodium - were found in the Red Lake macroflora, pollen was absent in the samples analysed by Mathews and Rouse (1963). Furthermore, fossil leaves belonging to Quercus are the dominant floral component in the Red Lake macroflora (4 species, each with several specimens), but Quercus pollen amounted to only $4 \%$ of the pollen assemblage counted by Mathews and Rouse (1963). However, these differences in the occurrence and relative abundance of taxa between the macroand microfloras may reflect sampling of different lithologies for the macro- and microflora, reflecting different edaphic settings, as well as the taphonomy of pollen versus leaves resulting from differences in facies. Pinus pollen, at $10 \%$, likely reflects a distant rather than a local source, whereas Pseudotsuga and Tsuga, present as a shoot and seed, more likely were growing near the lake. It must also be noted that this report on macrofossils is based on small collections, and it is expected that more extensive collection will reveal greater diversity and yield more representative abundance data.

The local area of the Red Lake Mine middle Miocene flora was reconstructed as wetter and warmer than the same area and elevation today (Tabs 3, 4). The present-day topography of the Coastal Mountain Range and the north-south orientation of the Cascade Mountain Range forms a rainshadow, creating an arid to semiarid climate to the lee of these ranges. However, as these mountain ranges were still uplifting during the middle Miocene, an orographic effect on air masses would not have been as prominent as it is today (Takeuchi et al., 2007; Potter and Szatmari, 2009). Therefore, moist air moving inland into British Columbia from over the Pacific Ocean would not have been significantly impeded during the middle Miocene, thus contributing to the high levels of precipitation and humidity estimated in this study (Graham, 1999; Takeuchi et al., 2007).

Climatic estimates similar to those we report here for Red Lake were made for other middle to late Miocene plant fossil sites in northwestern North America (Tab. 5). Palaeoclimate estimates using CLAMP from Pickett Creek, a late Miocene fossil plant assemblage from Idaho, show a climate comparable to Red Lake. Pickett Creek was estimated to be slightly warmer and drier than Red Lake (MAT $\sim 13^{\circ} \mathrm{C}$, WMMT $\sim 24^{\circ} \mathrm{C}, \mathrm{CMMT} \sim 3^{\circ} \mathrm{C}$, GSP $\sim 69 \mathrm{~cm}$, relative humidity $\sim 67 \%$ ), with growing season precipitation distributed over a slightly longer growing season ( 7.8 months) 
and, similar to Red Lake, without a notable dry season (3-WET $\sim 21 \mathrm{~cm}, 3$-DRY $\sim 15 \mathrm{~cm}$ ) (Buechler et al., 2007).

Climate estimates from Dillhoff et al. (2014) for the late Miocene Vasa Park microflora (WA) from coexistence analysis (nearest living relative method), indicate the occurrence of a dry season (wettest month precipitation $12-24 \mathrm{~cm}$, driest month precipitation 1-4 cm), in contrast to Red Lake. The temperature range for Vasa Park indicates that MAT was somewhat warmer than Red Lake (MAT 12$17^{\circ} \mathrm{C}$, CMMT $\sim-0.3-3^{\circ} \mathrm{C}$, WMMT $\sim 23-26^{\circ} \mathrm{C}$ ) (Dillhoff et al., 2014). The higher range of the temperature estimates for Vasa Park may, however, be the result of differences between the two methods used to estimate MAT (NLR vs. CLAMP) or may reflect shifts in climate to seasonal dryness from the middle to late Miocene, as well as differences in regional geography and elevation.

Mathews and Rouse (1963) speculated that Pinaceae-dominated forests may have been widespread in the Miocene British Columbia Interior uplands, and proposed that broadleaf vegetation rich in Ulmaceae and Carya surrounded the Miocene Red Lake site. Our data, based on a small macrofloral collection, suggests that the ancient Red Lake was surrounded by a diverse forest rich in oak species, together with other Fagaceae (Castanea, Fagus), Acer, Liquidambar, Platanus, Tilia, Trochodendraceae, alders and birch (Betulaceae), with a scattering of cedars (Cupressinocladus), Douglas fir (Pseudotsuga), hemlock (Tsuga) and rare Ginkgo, with dawn redwood (Metasequoia) and swamp cypress (Taxodium) in swampy areas on the lake margins. Comparable mixes of tree genera found in the Red Lake Miocene macroflora are absent from presentday forests of the Pacific Northwest and, apart from the Asian elements (e.g., Ginkgo, Metasequoia, Trochodendraceae), are more typical of the present-day deciduous forests and cypress swamps of eastern North America (Baskin and Baskin, 2016). This middle Miocene lakeside forest grew close to or at the modern elevation and under a climate not yet affected by a rainshadow resulting from the rise of the Cascade and Coastal Mountain Ranges; as such, the forest experienced a relatively wet climate with little or no seasonal dryness, and mild winters (Tabs 3,4) - a dramatic contrast to the contemporary vegetation and climate.

\section{CONCLUSIONS}

Included within the Red Lake Miocene macroflora were a single Ginkgo leaf, rare foliage of the conifers Pseudotsuga (cf. P. sonomensis), Metasequoia and Taxodium (cf. T. dubium), and likely also Chamaecyparis or Thuja (as Cupressinocladus sensu Zijistra and Kvaček 2010). Broadleaf ("dicot") angiosperm leaves dominated the flora, including a maple (Acer), alder (Alnus harneyana), beech (Fagus cf. F. pacifica), birch (Betula thor), chestnut (Castanea spokanensis), elm (Ulmus speciosa), Trochodendraceae (Zizyphoides auriculata), sycamore (Platanus dissecta), and leaves of a white oak (Quercus prelobata) and 3 red or pin oaks (Quercus columbiana, Q. pseudolyrata and an unnamed Quercus). Also present were several seeds and other reproductive structures, including Pinaceae seeds (cf. Tsuga sonomensis), an Acer samara (cf. A. brownii), and infructescences of Liquidambar, Nordenskioeldia interglacialis (Trochodendraceae) and Tilia pedunculata (Malvaceae). The overall impression is of a broadleaved deciduous forest rich in oaks and other Fagaceae (Castanea, Fagus), together with Acer, Betulaceae, Liquidambar, Platanus, Tilia and Ulmus, with rare Ginkgo and coniferous elements in the forest or within localized swamp areas (e.g., Taxodium). Apart from the presence of some rare East Asian elements (Metasequoia, Ginkgo, Trochodendraceae), floristically the assemblage corresponds well with presentday deciduous forests and cypress swamps of eastern North America, combined with a small number of taxa restricted today to western North America (e.g., Pseudotusga). The mix of genera of conifers and angiosperms present in the Red Lake macroflora corresponds well with the sets of taxa found across a number of middle Miocene macrofloras reported from the Pacific Northwest of the U.S. (Tab. 1), and includes species also found in those floras. The lack of Pinus foliage and leaves of typical present-day broadleaved taxa such as Mahonia in the Red Lake macroflora is in marked contrast to many other regional Miocene floras, but this difference may just reflect sampling effectiveness as well as taphonomy.

Palaeoclimate estimates derived using CLAMP reconstruct the climate for the Red Lake flora as mild, with more or less evenly distributed precipitation and with limited winter 
frost. These values are in agreement with similar contemporaneous fossil plant assemblages from the middle Miocene of the Pacific Northwest (Tab. 5), which indicates that a relatively stable climate persisted throughout the region during the middle Miocene. The stable and mild climate likely resulted from the limited orographic influence in the region, as the Cascade and Coastal Mountain Ranges were still uplifting at this time and had not yet reached their highest extent (Graham, 1999; Reiners et al., 2002; Potter and Szatmari, 2009). The moist air moving inland across the Pacific Northwest from over the Pacific Ocean would not have been obstructed by these mountain ranges; that would have contributed to the wet and humid climates that were present in these now-arid regions. Dillhoff et al. (2014) proposed that the warm and mild climate of the Pacific Northwest during the Miocene acted as a climatic refugium for some taxa amidst the increasing seasonality and cooling temperatures of the late Miocene, which ultimately led to the emergence of grasslands throughout the interior of North America (Retallack et al., 2002; Retallack, 2004; Strömberg, 2005; Retallack, 2007; Harris et al., 2017).

\section{ACKNOWLEDGEMENTS}

We thank S. Manchester for advice on identifying Juglandaceae, Trochodendraceae and Tilia fruits, T. Reichgelt for assistance with CLAMP, and M. Sudermann, J. Vachon and S. Schira for assistance with photography of the Red Lake collections. DRG thanks G. Simandl and J. Britton for advice on the Red Lake Mine geology. We also thank Dieter Uhl and an anonymous reviewer for their helpful suggestions for improvements to the original manuscript. Funding for this work was provided by the Natural Sciences and Engineering Research Council of Canada (NSERC) through Discovery Grants to DRG (2016-04337) and JFB (1334).

\section{REFERENCES}

APG IV [Angiosperm Phylogeny Group IV], 2016. An update of the Angiosperm Phylogeny Group classification for the orders and families of flowering plants: APG IV. Botanical Journal of the Linnean Society 181(1), 1-20.

Axelrod, D.I., 1964. The Miocene Trapper Creek flora of southern Idaho. University of California Publications in Geological Sciences 51, 1-161.

Axelrod, D.I., Arroyo, M.K., Raven, P.H., 1991. Historical development of temperate vegetation in the Americas. Revista Chilena de Historia Natural 64, 413-446.
Aylen, P.B., Simandl, G.J., Simandl, J., 2004. Leonardite at Red Lake deposit, British Columbia, Canada. In: George J. Simandl, G.J., William J. McMillan, W.J., Nicole Robinson, N. (eds), Industrial Minerals with emphasis on Western North America. British Columbia Ministry of Energy Mines and Petroleum Resources, Paper 2004-2, pp. 239-242.

Barrón, E., Averyanova, A., Kvaček, Z., Momohara, A., Pigg, K.B., Popova, S., Postigo-Mijarra, J.M., Tiffney, B.H., Utescher, T., Zhou, Z.K., 2017. The fossil history of Quercus. In: Gil-Pelegrín, E., PegueroPina, J.J., Sancho-Knapik, D. (eds), Oaks physiological ecology. Exploring the functional diversity of genus Quercus L. Springer, Chambridge, pp. 39-105.

Baghai, N.L., Jorstad, R.B., 1995. Paleontology, paleoclimatology and paleoecology of the late middle Miocene Musselshell Creek flora, Clearwater County, Idaho; a preliminary study of a new fossil flora. Palaios 10(5), 424-436.

Baskin, J.M., Baskin, C.C., 2016. Origins and relationships of the Mixed Mesophytic Forest of OregonIdaho, China, and Kentucky: Review and synthesis. Annnals of the Missouri Botanical Garden 101(3), 525-552.

Bell, W.A., 1962. Catalogue of types and figured specimens of fossil plants in the Geological Survey of Canada collections. Geological Survey of Canada, Ottawa.

Berry, E.W., 1929. The age of the St. Eugene silt in the Kootenay Valley, British Columbia. Transactions of the Royal Society of Canada, 3d Series, 23(sec. 4), 4748.

Berry, E.W., 1931. A Miocene flora from Grand Coulee, Washington. United States Geological Survey, Professional Paper 170-C, 31-42.

Berry, E.W., 1934. Miocene plants from Idaho. United States Geological Survey, Professional Paper 185-E, 97-125.

Bevier, M.L., 1983. Regional stratigraphy and age of Chilcotin Group basalts, south-central British Columbia. Canadian Journal of Earth Sciences 20(4), 515-524.

Bolton, T.E., 1994. Catalogue of types and figured specimens of fossil plants in the Geological Survey of Canada collections (Vol. 2). Geological Survey of Canada, Ottawa.

Borgardt, S.J., Pigg, K.B., 1999. Anatomical and developmental study of petrified Quercus (Fagaceae) fruits from the Middle Miocene, Yakima Canyon, Washington, USA. American Journal of Botany 86(3), 307-325.

Buechler, W.K., Dunn, M.T., Rember, W.C., 2007. Late Miocene Pickett Creek Flora of Owyhee County, Idaho. Contributions from the Museum of Paleontology, The University of Michigan 31(12), 305-362.

Champigny, N., Henderson, C.M., Rouse, G.E., 1981. New evidence for the age of the Skonun Formation, Queen Charlotte Islands, British Columbia. Canadian Journal of Earth Sciences 18(12), 1900-1903. 
Chaney, R.W., 1927. Geology and paleontology of the Crooked River Basin, with special reference to the Bridge Creek flora. Carnegie Institution of Washington, Publication 346, 45-138.

Chaney, R.W., 1959. Miocene floras of the Columbia Plateau, Part I: Composition and interpretation. Carnegie Institution of Washington, Publication 617, 1-134.

Chaney, R.W., Axelrod, D.I., 1959. Miocene Floras of the Columbia Plateau, Part II: Systematic considerations. Carnegie Institution of Washington, Publication 617, 135-224, 44 plates.

Christenhusz, M.J., Reveal, J.L., Farjon, A., Gardner, M.F., Mill, R.R., Chase, M.W., 2011. A new classification and linear sequence of extant gymnosperms. Phytotaxa 19(1), 55-70.

Clague, J.J., 1974. The St. Eugene Formation and the development of the southern Rocky Mountain Trench. Canadian Journal of Earth Sciences 11(7), 916-938.

Crane, P.R., Stockey, R.A., 1987. Betula leaves and reproductive structures from the Middle Eocene of British Columbia, Canada. Canadian Journal of Botany 65, 2490-2500.

Crane, P.R., Manchester, S.R., Dilcher, D.L., 1991. Reproductive and vegetative structure of Nordenskioldia (Trochodendraceae), a vesselless dicotyledon from the early Tertiary of the Northern Hemisphere. American Journal of Botany 78(10), 1311-1334.

Cross, A.T., Taggart, R.E., 1982. Causes of short-term sequential changes in fossil plant assemblages: some considerations based on a Miocene flora of the northwest United States. Annals of the Missouri Botanical Garden 69(3), 676-734.

Dawson, G.M., 1895. Report on the area of the Kamloops map sheet, British Columbia. Geological Survey of Canada, Annual Report 7, Part B.

Dawson, J.W., 1883. On the Cretaceous and Tertiary floras of British Columbia and the Northwest Territory. Procedings and Transactions of the Royal Society of Canada, Series 1, Volume 1, Section IV, 15-34, with 8 plates.

Dillhoff, R.M., Dillhoff, T.A., Jijina, A.P., Strömberg, C.A.E., 2014. The Vasa Park flora, King County, Washington, USA: A window into the Late Miocene of the Pacific Northwest. In: Stevens, W.D., Montiel, O.M., Raven, P.H. (eds), Paleobotany and biogeography: A festschrift for Alan Graham in his 80th year. Missouri Botanical Garden, St. Louis, Chapter 5, pp. 64-97.

Dostal, J., Hamilton, T.S., Church, B.N., 1996. The Chilcotin basalts, British Columbia (Canada): geochemistry, petrogenesis and tectonic significance. Neues Jahrbuch für Mineralogie - Abhandlungen 170(2), 207-229.

Eberle, J.J., Greenwood, D.R., 2017. An Eocene brontothere and tillodonts (Mammalia) from British Columbia, and their paleoenvironments. Canadian Journal of Earth Sciences 54(9), 981-992.
Ellis, B., Daly, D.C., Hickey, L.J., Mitchell, J.V., Johnson, K.R., Wilf, P., Wing, S.L., 2009. Manual of leaf architecture. Cornell University Press, Ithaca, New York.

Environment and Climate Change Canada, 2018. Canadian Climate Normals; 1971-2000 Climate Normals \& Averages. https://climate.weather. gc.ca/climate_normals/index_e.html [accessed 9 December 2018]

Graham, A., 1963. Systematic revision of the Sucker Creek and Trout Creek Miocene floras of southeastern Oregon. American Journal of Botany 50(9), 921-936.

Graham, A., 1993. History of the vegetation: Cretaceous (Maastrichtian) - Tertiary. Flora of North America 1, 57-70.

Graham, A., 1999. Late Cretaceous and Cenozoic History of North American Vegetation. Oxford University Press, New York.

Greenwood, D.R., 2007. Fossil angiosperm leaves and climate: from Wolfe and Dilcher to Burnham and Wilf. Courier Forschungsinstitut Senckenberg 258, 95-108.

Greenwood, D.R., Pigg, K.B., Basinger, J.F., Devore, M.L., 2016. A review of paleobotanical studies of the Early Eocene Okanagan (Okanogan) Highlands floras of British Columbia, Canada and Washington, U.S.A. Canadian Journal of Earth Sciences 53(6), 548-564.

Gurney, S., 2016. Red Lake bulk sample site \#534172. British Columbia Geological Survey Assessment Report 35982.

Harris, E.B., Strömberg, C.A., Sheldon, N.D., Smith, S.Y., Vilhena, D.A., 2017. Vegetation response during the lead-up to the middle Miocene warming event in the Northern Rocky Mountains, USA. Palaeogeography, Palaeoclimatology, Palaeoecology 485, 401-415.

Henrot, A.J., Utescher, T., Erdei, B., Dury, M., Hamon, N., Ramstein, G., Krapp, M., Herold, N., Goldner, A., Favre, E., Munhoven, G., 2017. Middle Miocene climate and vegetation models and their validation with proxy data. Palaeogeography, Palaeoclimatology, Palaeoecology 467, 95-119.

Hickey, L.J., Johnson, K.R., Dawson, M.R., 1988. The stratigraphy, sedimentology, and fossils of the Haughton Formation: A post-impact crater-fill, Devon Island, NWT, Canada. Meteoritics 23(3), 221-231.

Hills, L.V., Ogilvie, R.T., 1970. Picea banksii n. sp. Beaufort Formation (Tertiary), northwestern Banks Island, Arctic Canada. Canadian Journal of Botany 48, 457-464.

Hills, L.V., Klovan, J.E., Sweet, A.R., 1974. Juglans eocinerea n. sp., Beaufort Formation (Tertiary), southwestern Banks Island. Canadian Journal of Botany 52, 65-90.

Hollick, A., 1927. The flora of the Saint Eugene silts, Kootenay Valley, British Columbia. Memoirs of the New York Botanical Garden 7, 389-465. 
Hopkins, Jr, W.S., 1968. Subsurface Miocene rocks, British Columbia-Washington, A palynological investigation. Geological Society of America Bulletin 79(6), 763-768.

Huegele, I.B., Spielbauer, R.J., Manchester, S.R., 2020. Morphology and systematic affinities of Platanus dissecta Lesquereux (Platanaceae) from the Miocene of western North America. International Journal of Plant Sciences, DOI: 10.1086/706453.

Ickert-Bond, S.M., Pigg, K.B., Wen, J., 2005. Comparative infructescence morphology in Liquidambar (Altingiaceae) and its evolutionary significance. American Journal of Botany 92(8), 1234-1255.

Kasbohm, J., Schoene, B., 2018. Rapid eruption of the Columbia River flood basalt and correlation with the mid-Miocene climate optimum. Sciences Advances 4(9), eaat8223, DOI: 10:1126/sciadv.aat8223.

Knowlton, F.H., 1902. Fossil flora of the John Day Basin Oregon. United States Geological Survey, Bulletin 204, 1-174.

Kowalski, E.A., Dilcher, D.L., 2003. Warmer paleotemperatures for terrestrial ecosystems. Proceedings of the National Academy of Sciences 100(1), 167-170.

Kvaček, J., 2015. Elatocladus velenovskyi nom. nov., a characteristic conifer of the Bohemian Cretaceous Basin. Palaeontographica Abteilung B 292(1-3), 79-93.

Lott, T.A., Manchester, S.R., Corbett, S.L., 2019. The Miocene flora of Alum Bluff, Liberty County, Florida. Acta Palaeobotanica 59(1), 75-129.

Manchester, S.R., 1994. Inflorescence bracts of fossil and extant Tilia in North America, Europe, and Asia: Patterns of morphologic divergence and biogeographic history. American Journal of Botany 81(9), 1176-1185.

Manchester, S., Rember, W., 2014. Taxonomic composition of the Middle Miocene Clarkia flora of northern Idaho. Abstract C2006-607 in, The Miocene vegetation and environment of Western North America. Botanical Society of America Annual Meeting. Boise, Idaho. July 29, 2014. http:// www.botanyconference.org/engine/search/index. php?func=detail\&aid=607 [accessed Apr. 25, 2020]

Manchester, S.R., Crane, P.R., Dilcher, D.L., 1991. Nordenskioldia and Trochodendron (Trochodendraceae) from the Miocene of northwestern North America. Botanical Gazette 152(3), 357-368.

Manchester, S.R., Pigg, K.B., Devore, M.L., 2018. Trochodendraceous fruits and foliage in the Miocene of Western North America. Fossil Imprint 74(1, 2), $45-54$.

Martin, H.A., Rouse, G.E., 1966. Palynology of late Tertiary sediments from Queen Charlotte Islands, British Columbia. Canadian Journal of Botany 44, 171-208.

Matthews Jr, J.V., Ovenden, L.E., 1990. Late Tertiary plant macrofossils from localities in Arctic/Subarctic North America: a review of the data. Arctic 43(4), 364-392.
Mathews, W.H., 1989. Neogene Chilcotin basalts in south-central British Columbia: Geology, ages, and geomorphic history. Canadian Journal of Earth Sciences 26, 969-982.

Mathews, W.H., Rouse, G.E., 1963. Late Tertiary volcanic rocks and plant-bearing deposits in British Columbia. Geological Society of America Bulletin 74(1), 55-60.

Mathews, W.H., Rouse, G.E., 1984. The Gang RanchBig Bar area, south-central British Columbia: stratigraphy, geochronology, and palynology of Tertiary beds and their relationship to the Fraser Fault. Canadian Journal of Earth Sciences 21, 1132-1144.

McIver, E.E., Basinger, J.F., 1999. Early Tertiary floral evolution in the Canadian High Arctic. Annals of the Missouri Botanical Garden 86(2), 523-545.

Mustoe, G.E., Leopold, E.B., 2014. Paleobotanical evidence for the post-Miocene uplift of the Cascade Range. Canadian Journal of Earth Sciences 51, 809-824.

Penhallow, D.P., 1908. A report on Tertiary plants of British Columbia, collected by Lawrence M. Lambe in 1906 together with a discussion of previously recorded Tertiary floras. Canada Department of Mines, Geological Survey Branch, No. 1013, 1-167.

Peppe, D.J., Royer, D.L., Cariglino, B., Oliver, S.Y., Newman, S., Leight, E., Enikolopov, G., Fernandez-Burgos,M., Herrera, F., Adams, J.M., Correa, E., Currano, E.D., Erickson, J.M., Hinojosa, L.F., Hoganson, J.W., Iglesias, A., Jaramillo, C.A., Johnson, K.R., Jordan, G.J., Kraft, N.J.B., Lovelock, E.C., Lusk, C.H., Niinemets, Ü., Peñuelas, J., Rapson, G., Wing, S.L., Wright, I.J., 2011. Sensitivity of leaf size and shape to climate: global patterns and paleoclimatic applications. New Phytolologist 190, 724-739.

Pigg, K.B., Ickert-Bond, S.M., Wen, J., 2004. Anatomically preserved Liquidambar (Altingiaceae) from the middle Miocene of Yakima Canyon, Washington state, USA, and its biogeographic implications. American Journal of Botany 91(3), 499-509.

Pigott, D., 2006. 550. Tilia endochrysea: Tiliaceae. Curtis's Botanical Magazine 23(1), 56-61.

Pinson, J.B., Manchester, S.R., Sessa, E.B., 2018. Culcita remberi sp. nov., an understory fern of Cyatheales from the Miocene of Northern Idaho. International Journal of Plant Sciences 179(8), 635-639.

Potter, P.E., Szatmari, P., 2009. Global Miocene tectonics and the modern world. Earth-Science Reviews 96(4), 279-295.

Pound, M.J., Haywood, A.M., Salzmann, U., Riding, J.B., Lunt, D.J., Hunter, S.J., 2011. A Tortonian (late Miocene, 11.61-7.25 Ma) global vegetation reconstruction. Palaeogeography, Palaeoclimatology, Palaeoecology 300(1-4), 29-45.

Prader, S., Kotthoff, U., McCarthy, F.M.G., Schmiedl, G., Donders, T.H., Greenwood, D.R., 2017. Vegetation and climate development of the New Jersey Hinterland during the late Middle Miocene (IOPD 
Exp. 313 Site M0027). Palaeogeography, Palaeoclimatology, Palaeoecology 485, 854-868.

Prader, S., Kotthoff, U., Greenwood, D.R., McCarthy, F.M.G., Schmiedl, G., Donders, T.H., 2020. New Jersey's paleoflora and eastern North American climate through Paleogene-Neogene warm phases. Review of Palaeobotany and Palynology 279, 104224.

Read, P.B., 1989. Tertiary stratigraphy and industrial minerals, Bonaparte to Deadman Rivers (NTS 92P/2, 3). British Columbia Geological Survey, British Columbia Ministry of Energy, Mines and Petroleum Resources, Open File 1989-21.

Read, P.B., 1992. Miocene stratigraphy and industrial minerals, Bonaparte to Deadman River area, southern British Columbia (92I/14, 15; 92P/2,3). British Columbia Geological Survey, British Columbia Ministry of Energy, Mines and Petroleum Resources, Geological Fieldwork, 1988, Paper 1989-1.

Read, P.B., 1996. Geology, Red Lake open pit, Kamloops Mining Division (92I/15w/2). British Columbia Geological Survey, British Columbia Ministry of Energy, Mines and Petroleum Resources, Assessment Report 25358, pp. 23, 4 leaves.

Read, P.B., 2000. Geology of the Arrowstone Hills: 5-16, Ch. 4. In: Read, P.B. (ed.), Geology and industrial minerals of the Tertiary basins, south-central British Columbia. British Columbia Geological Survey, British Columbia Ministry of Energy and Mines, GeoFile 2000-3. Available from https://www2.gov. bc.ca/gov/content/industry/mineral-explorationmining/british-columbia-geological-survey/publications/geofiles\#2000 [last accessed 01 August 2020]

Reiners, P.W., Ehlers, T.A., Garver, J.I., Mitchell, S.G., Montogmery, D.R., Vance, J.A., Nicolescu, S., 2002. Late Miocene exhumation and uplift of the Washington Cascade Range. Geology 30(9), 767-770.

Retallack, G.J., 2004. Late Miocene climate and life on land in Oregon within a context of Neogene global change. Palaeogeography, Palaeoclimology, Palaeoecology 214(1,2), 97-123.

Retallack, G.J., 2007. Cenozoic paleoclimate on land in North America. Journal of Geology 115(3), 271-294.

Retallack, G.J., Tanaka, S., Tate, T., 2002. Late Miocene advent of tall grassland paleosols in Oregon. Palaeogeography, Palaeoclimatology, Palaeoecology 183(3,4), 329-354.

Rouse, G.E., Mathews, W.H., 1979. Tertiary geology and palynology of the Quesnel Area, British Columbia. Bulletin of Canadian Petroleum Geology 27(4), 418-445.

Robichaux, R.H., Taylor, D.W., 1977. Vegetation-analysis techniques applied to late Tertiary fossil floras from the Western United States. Journal of Ecology 65(2), 643-660.

Scott, R.A., Barghoorn, E.S., Prakash, U., 1962. Wood of Ginkgo in the Tertiary of western North America. American Journal of Botany 49(10), 1095-1101.

Simandl, G.J., Simandl, J., Aylen, P.B., 2001. Leonardite-type material at Red Lake Diatomite Deposit, Kamloops Area, British Columbia. British
Columbia Geological Survey, British Columbia Ministry of Energy and Mines, Geological Fieldwork 2000, Paper 2000-1 pp. 371-378.

Smiley, C.J., Gray, J., Huggins, L.M., 1975. Preservation of Miocene fossils in unoxidized lake deposits, Clarkia, Idaho. Journal of Paleontology 49(5), 833-844.

Smith, H.V., 1941. A Miocene Flora from Thorn Creek, Idaho. American Midland Naturalist 25(3), 473-522.

Smith, M., Manchester, S.R., 2019. A new species of "gigantic" capsular fruits of Vaccinioideae from the Miocene of Idaho. Palaeontologia Electronica 22.3.65, 1-7. https://doi.org/10.26879/982

Strömberg, C.A.E., 2005. Decoupled taxonomic radiation and ecological expansion of open-habitat grasses in the Cenozoic of North America. Proceedings of the National Academy of Sciences of the United States of America 102(34), 11980-11984.

Takeuchi, A., Larson, P.B., Suzuki, K., 2007. Influence of paleorelief on the mid-Miocene climate variation in southeastern Washington, northeastern Oregon, and western Idaho, USA. Palaeogeography, Palaeoclimatology, Palaeoecology 254(3,4), 462-476.

Tanai, T., Wolfe, J.A., 1977. Revisions of Ulmus and Zelkova in the middle and late Tertiary of western North America. United States Geological Survey, Professional Paper 1026, 1-14, 4 plates.

The Imaging Source, 2015. IC Measure, manual onscreen image measurement and image acquisition. Website: http://www.theimagingsource.com/en_US/ support/downloads/details/icmeasure/ [accessed 20 March 2016]

Wang, Y.H., Ferguson, D.K., Feng, G.P., Wang, Y.F., Zhilin, S.G., Li, C.S., Svetlana, P.T., Yang, J., Ablaev, A.G., 2009. The phytogeography of the extinct angiosperm Nordenskioeldia (Trochodendraceae) and its response to climate changes. Palaeogeography, Palaeoclimatology, Palaeoecology $280(1,2), 183-192$.

West, C.K., Greenwood, D.R., Basinger, J.F., 2019. The late Paleocene to early Eocene Arctic megaflora of Ellesmere islands, Nunavut, Canada. Palaeontographica Abt. B 300 (1-6), 47-163.

Wheeler, E.A., Dillhoff, T.A., 2009. The middle Miocene wood flora of Vantage, Washington, USA. IAWA Journal, Supplement 7, 1-101.

White, J.M., Ager T.A., Adam, D.P., Leopold, E.B., Liu, G., Jetté H., Schweger, C.E., 1997. An 18 million year record of vegetation and climate change in northwestern Canada and Alaska: tectonic and global climatic correlates. Palaeogeography, Palaeoclimatology, Palaeoecoogy 130, 293-306.

Whitlock, C., Dawson, M.R., 1990. Pollen and vertebrates of the early Neogene Haughton Formation, Devon Island, Arctic Canada. Arctic 43(4), 324-330.

Wilf, P., Wing, S.L., Greenwood, D.R., Greenwood, C.L., 1998. Using fossil leaves as paleoprecipitation indicators: An Eocene example. Geology 26, 203-208. 
Williams, C.J., Mendell, E.K., Murphy, J., Johnson, A.H., Richter, S.L,. 2008. Paleoenvironmental reconstruction of a Middle Miocene forest from the western Canadian Arctic. Palaeogeography, Palaeoclimatology, Palaeoecology 261(1,2), 160-176.

Wing, S.L., 1998. Tertiary vegetation of North America as a context for mammalian evolution. In: Janis, C.M., Scott, K.M., Jacobs, L.L. (eds) Evolution of Tertiary mammals of North America, v. 1. Cambridge, New York, pp. 37-65.

Wing, S.L., Greenwood, D.R., 1993. Fossils and fossil climates: the case for equable Eocene continental interiors. Philosophical Transactions of the Royal Society, London B 341, 243-252.

Wolfe, J.A., 1966. Tertiary plants from the Cook Inlet region, Alaska. United States Geological Survey, Professional Paper 398-B, B1-B32, 8 plates.

Wolfe, J.A., Tanai, T., 1980. The Miocene Seldovia Point flora from the Kenai Group, Alaska. United States Geological Survey, Professional Paper 1105, 1-47.
Wolfe, J.A., Tanai, T., 1987. Systematics, phylogeny, and distribution of Acer (maples) in the Cenozoic of Western North America. Journal of the Faculty of Science, Hokkaido University, Ser. IV., 22(1), $1-246$.

Yang, J., Spicer, R.A., Spicer, T.E., Li, C.S., 2011. 'CLAMP Online': A new web-based palaeoclimate tool and its application to the terrestrial Paleogene and Neogene of North America. Palaeobiodiversty and Palaeoenvironments 91(3), 163-183.

Yang, J., Spicer, R.A., Spicer, T.E., Arens, N.C., Frédéric, J.M.B., Tao, S., Kennedy, E.M., Herman, A.B., Steart, D.C., Gaurav, S., Mehrotra, R.C., Valdes, P.J., Mehrotra, N.C., Zhou, Z.-K., Lai, J.-S., 2015. Leaf form-climate relationships on the global stage: An ensemble of characters. Global Ecology and Biogeography 24, 1113-1125.

Zijlstra, G., Kvaček, Z., 2010. (1924) Proposal to conserve the name Cupressinocladus against Libocedrites (fossil Coniferophyta). Taxon 59(1), 301. 